\title{
Effect of fluoxetine hydrochloride on the histological structure of the cerebellar cortex of albino rat offspring of treated mothers
}

\author{
By \\ Amany M. Abo-Ouf \\ Department of Anatomy and Embryology, Faculty of Medicine (Girls), Al-Azhar \\ University \\ Mail: amanymostafa.medg@azhar.edu.eg.com or m_aouf2000@yahoo.com
}

\begin{abstract}
Background: Fluoxetine hydrochloride is one of the most commonly used antidepressants in the selective serotonin reuptake inhibitor (SSRI) class.

Objectives: Demonstrating the effect of fluoxetine hydrochloride on the histological structure of the cerebellar cortex of albino rat offspring of treated mothers by 20 and 40 mgs throughout the first 2 weeks after delivery, and 40mg throughout the last week of pregnancy and the first 2 weeks after delivery.

Materials and Methods: Sixty pregnant rats and 180 of their offspring were used in this work. They were divided equally into two main groups; A-control group (Group C) and B-treated group (Group T). The pregnant rats and their offspring of the control group were divided equally into $\mathrm{C} 1, \mathrm{C} 2$ and $\mathrm{C} 3$. Immediately after delivery, each delivered rat of $\mathrm{C} 1$ and $\mathrm{C} 2$ was given $0.18 \mathrm{ml}$ and $0.36 \mathrm{ml}$ of distilled water respectively for two weeks. Each pregnant rat of C3 was given $0.36 \mathrm{ml}$ of distilled water throughout the last week of pregnancy and for 2 weeks after delivery. The pregnant rats and their offspring of the treated group were divided equally into T1, T2 and T3. Immediately after delivery each delivered rat of T1 and T2 was given $0.18 \mathrm{ml}$ (Containing $0.36 \mathrm{mg}$ of fluoxetine hydrochloride) and $0.36 \mathrm{ml}$ (Containing $0.72 \mathrm{mg}$ of fluoxetine hydrochloride) of distilled water respectively for 2 weeks. Each pregnant rat of T3 was given $0.36 \mathrm{ml}$ of distilled water (Contained $0.72 \mathrm{mg}$ of fluoxetine hydrochloride) throughout the last week of pregnancy and for 2 weeks after delivery. The treatments were given once/day orally. The specimens were collected at two ages, i.e. 1-week and 2-weeks old. The cerebella of all studied offspring were used for light microscopic examination. In addition, the cerebella of 2-weeks old offspring of all groups were used for electron microscopic examination and morphometric study.
\end{abstract}

Results: Light and electron microscopic examination and morphometric studies demonstrated that fluoxetine hydrochloride induced various signs of delayed development of the cerebellar cortex. It also induced degeneration and necrosis of the cerebellar cells and nerve fibers in the form of cytoplasmic vacuoles, dilated rough endoplasmic reticulum, swollen mitochondria with destructed cristae, degenerated mitochondria and nuclear changes in the form of karyolysis, pyknosis and karyorrhexis. Also, there was decrease in the number of Purkinje cells.

Conclusion: Fluoxetine hydrochloride induced various deleterious changes in the histological structure of the cerebellar cortex of albino rat offspring of treated mothers. These changes were directly proportional with increasing the dose and duration of its administration.

Key words: animals, rat, pregnancy, lactation, SSRIs, fluoxetine, cerebellum. 


\section{INTRODUCTION}

During and following pregnancy, women are at high risk of experiencing depression (Kiryanova et al., 2013). Up to $20 \%$ of women experience mood disorders, such as depression and anxiety, during pregnancy (Underwood et al., 2016 and Vigod et al., 2016). Depression in pregnancy may reduce the mother's capacity for self-care which may compromise the woman's physical and mental health and may reduce fetal monitoring or restrict the growth and development of the fetus. The consequences of postnatal depression on child development have been the focus of several studies which showed changes on cognitive, emotional, and social development in children (Leigh and Milgrom, 2008). The use of antidepressant treatment during pregnancy is increasing, and selective serotonin reuptake inhibitors (SSRIs) are the most widely prescribed antidepressants in pregnant women (Kaihola et al., 2016). Fluoxetine is a selective serotonin reuptake inhibitor used to treat depression in pregnant and nursing women (Filho et al., 2014). SSRIs primarily act by the inhibition of serotonin transporter at the presynaptic neuron, thus increasing extracellular serotonin levels (Rotem-Kohavi and Oberlander, 2017). It is highly absorbed after oral administration, metabolized in the liver and then excreted by the urine (Yilmaz et al., 2016). Fluoxetine hydrochloride is a safe and well tolerated drug; however, adverse events are observed with high doses. Such adverse events include gastrointestinal problems (nausea, vomiting, and diarrhea); nervous system problems (insomnia, anxiety), and sexual dysfunction, bipolar disorders, balance disorder, metabolic disorders (hyponatremia), and organ failure (liver failure and renal failure) in rare cases (Ayaz et al., 2015), also SSRI treatment has been associated with increased risk of pregnancy complications such as preterm birth, neurodevelopmental risks and preeclampsia (Qiu et al., 2009 ; Wisner et al., 2009 and Rotem-Kohavi and Oberlander, 2017). Epidemiologic studies have suggested a link between maternal fluoxetine hydrochlorid use during pregnancy and an increased incidence of birth defects (Warkus, 2018). The neuroprotective effects of fluoxetine hydrochloride are reported by other findings (Jin et al., 2009 and Vizi et al., 2013). Gross brain structural alterations in offspring exposed to prenatal SSRIs have not been demonstrated (Brummelte et al., 2017). During organogenesis, medication can be teratogenic, thereby causing congenital malformations and serious damages that may lead to abortion (Czeizel et al., 2008). From this view, the neural effect of fluoxetine hydrochloride is controversial. So this work aimed to demonstrate the effect of fluoxetine hydrochloride on the histological structure of the cerebellar cortex of albino rat offspring of treated mothers by 20 and 40 mgs throughout the first two weeks after delivery, and $40 \mathrm{mg}$ throughout the last week of pregnancy and the first two weeks after delivery.

\section{MATERIALS AND METHODS}

\section{Drug:}

Fluoxetine hydrochloride (fluoxetine ${ }^{\circledR}$ ) was available in capsule forms, manufactured by Misr Company for 


\section{Effect of fluoxetine hydrochloride on the histological ...}

Pharmaceuticals. The human therapeutic dose is ranged from 20 to $40 \mathrm{mg} /$ day (Sengupata, 2016). In this work, 20 and $40 \mathrm{mgs}$ of fluoxetine hydrochloride were used. The equivalent doses of adult rat were calculated according to the formula of (Paget and Barnes, 1964) to be $0.36 \mathrm{mg} / \mathrm{rat}$ and $0.72 \mathrm{mg} / \mathrm{rat}$ respectively. According to (Donald et al., 1990), the contents of $20 \mathrm{mg}$ capsule $(20 \mathrm{mg}$ of fluoxetine hydrochloride) was dissolved in $10 \mathrm{ml}$ of distilled water. So the adult rat received $0.18 \mathrm{ml}$ and $0.36 \mathrm{ml}$ of distilled water that contained $0.36 \mathrm{mg}$ and $0.72 \mathrm{mg}$ of fluoxetine respectively. The distilled water alone or the distilled water that contained the drug were given by gastric tube as a single oral daily dose for the control and treated animals respectively.

\section{Animals:}

Ninety adult albino rats (60 female and 30 male) of local strain in addition to 180 of their offspring were used in this work. The average weight of the adult rats was about $120 \mathrm{~g}$. They were obtained and provided by veterinary care by the animal house of Faculty of Medicine for Girls, Al- Azhar University during the year of 2018. Each male was kept with 2 females in a separate cage to allow matting. The female that showed a vaginal plug was considered to be in the first day of pregnancy (Barcellona et al., 1977).Then each pregnant rat was kept in a separate cage until delivery. The offspring were kept with their mothers for feeding until weaning. The albino rats were observed and maintained on balanced diet and water (standard diet pellets- El-Nasr-company, Abo-Zaabal - Egypt). The pellets were consisted of $5 \%$ fibers, $3.5 \%$ fats, $6.5 \%$ ash and $20 \%$ proteins.
The 60 pregnant rats and 180 of their offspring were divided equally into two main groups; control and treated groups.

\section{A- Control group (Group C):}

The 30 pregnant rats and 90 of their offspring were divided equally into $\mathrm{C} 1$, $\mathrm{C} 2$ and $\mathrm{C} 3$.

I- C1: Immediately after delivery, each delivered rat was given $0.18 \mathrm{ml}$ of distilled water as a single oral daily dose for 2 weeks. The cerebella of 10 offspring were taken at the end of the 1st week (C1O1). The cerebella of the remained 20 offspring were taken at the end of the 2nd week (C1O2).

II- C2: Immediately after delivery, each delivered rat was given $0.36 \mathrm{ml}$ of distilled water as a single oral daily dose for 2 weeks. The cerebella of 10 offspring were taken at the end of the 1st week (C2O1). The cerebella of the remained 20 offspring were taken at the end of the 2nd week (C2O2).

III- C3: Each pregnant rat was given $0.36 \mathrm{ml}$ of distilled water as a single oral daily dose throughout the last week of pregnancy and for 2 weeks after delivery. The cerebella of 10 offspring were taken at the end of the 1st week (C3O1). The cerebella of the remained 20 offspring were taken at the end of the 2nd week (C3O2).

\section{B- Treated group (Group T):}

The 30 pregnant rats and 90 of their offspring were divided equally into $\mathrm{T} 1, \mathrm{~T} 2$ and $\mathrm{T} 3$.

I-T1: Immediately after delivery, each delivered rat was given $0.18 \mathrm{ml}$ of distilled water (containing $0.36 \mathrm{mg}$ of fluoxetine hydrochloride) as a single 
oral daily dose for 2 weeks.The cerebella of 10 offspring were taken at the end of the 1st week (T1O1). The cerebella of the remained 20 offspring were taken at the end of the 2 nd week (T1O2).

II- T2: Immediately after delivery, each delivered rat was given $0.36 \mathrm{ml}$ of distilled water (containing $0.72 \mathrm{mg}$ of fluoxetine hydrochloride) as a single oral daily dose for 2 weeks. The cerebella of 10 offspring were taken at the end of the 1st week (T2O1). The cerebella of the remained 20 offspring were taken at the end of the 2 nd week (T2O2).

III- T3: Each pregnant rat was given 0.36 $\mathrm{ml}$ of distilled water (containing 0.72 $\mathrm{mg}$ of fluoxetine hydrochloride) as a single oral daily dose throughout the last week of pregnancy and for 2 weeks after delivery. The cerebella of 10 offspring were taken at the end of the 1 st week (T3O1). The cerebella of the remained 20 offspring were taken at the end of the 2nd week (T3O2).

\section{Collection of the specimens and preparation for examination:}

The specimens were collected at two ages, i.e. 1-week and 2-weeks. The all offspring were anaesthetized lightly by diethyl ether inhalation. Each rat of all groups was decapitated and the cap and side walls of the cranium were carefully removed. The dura mater was carefully incised all around then raised up then, the cerebella were gently removed and rapidly immersed in suitable fixatives. Special care was done for the rats which their cerebella were used for electron microscopic examination. The rats were injected intracranially with glutraldehyde before decapitation of the skull cap, and the specimens were taken so rapid while the rats still alive. The cerebella of all studied offspring were used for light microscopic examination, in addition the cerebella of 2-weeks old offspring of all groups were used for electron microscopic examination and morphometric study.

\section{1- Light microscopic examination:}

The cerebella which were used for light microscopic examination were fixed by immersion in Bouin's solution for 3days (Suvarna et al., 2013). The specimens were dehydrated in ascending grades of ethyl alcohol and cleared in benzene. The specimens were impregnated for three changes in paraffin and were finally embedded in paraffin wax. The paraffin blocks were cut into serial sagittal sections at $5 ? \mathrm{~m}$ thick with a rotary microtome. Successive sagittal paraffin sections were attached to an albumenized glass slides. The haematoxylin and Eosin stain (Bancroft and Gamble, 2008) was used to study the cerebellar architectures. The images were taken by a microscope (Leica) DM750 connected to a digital camera in Anatomy Department, Faculty of Medicine for Girls, Al-Azhar University, Cairo. Egypt.

\section{2-Transmission electron microscopic examination:}

The superficial layers of the cerebella which used for electron microscopic examination were cut into small pieces. The specimens were immediately fixed in cold 5\% glutraldehyde and washed in 0.1 $\mathrm{ml}$ phosphate buffer (PH 7.2). Then, post fixed with $1 \%$ osmium tetraoxide (OsO4), dehydrated and embedded in epoxy resin. The semi-thin sections (1? $\mathrm{m}$ thick) were cut on an LKB ultratome, stained with 


\section{Effect of fluoxetine hydrochloride on the histological ...}

toluidine blue and examined by light microscope to determine the area that subjected to ultrathin cutting. The ultrathin sections (60 nm thick) were mounted on copper grids, and stained with uranyl acetate and lead citrate (Bancroft and Gamble, 2008):“The ultrathin sections were examined using $a$ transmission electron microscope (JEOL1010 EX II, Japan) at the Regional Mycology and Biotechnology Center, AlAzhar University, Cairo, Egypt.

\section{3- Morphometric study:}

The image analyser computer system Leica Qwin 500 (England) at the Regional Mycology and Biotechnology center, AlAzhar University, Cairo, Egypt was used to evaluate the thickness of the molecular layer and the number of the Purkinje cells of the studied groups by using haematoxylin and eosin stained sections. The ten slides of ten offspring albino rats were taken at the mid-sagittal sections of the cerebellar hemispheres of all groups. The central five folia were selected in each slide to measure the thickness of the molecular layer and to count the number of Purkinje cells. Measuring the thickness was done by taking 6 different thicknesses for each folium at magnification $\mathrm{x} 100$ using Image $J$ software version 1.48. Counting the number of Purkinje cells of the central five folia was done in special fixed squares. The means of the thickness of the molecular layers and the means of the numbers of the Purkinje cells of each folium were calculated. The cummulative mean thickness of the molecular layers and mean number of the Purkinje cells for each group were calculated statistically. The data was subjected to statistical analysis.

\section{Statistical Analysis:}

Statistical analysis of the thickness of the molecular layer and the counted Purkinje cells were carried out using the SPSS statistical package, the data were analyzed and statistical significance was determined by using one-way ANOVA followed by a Tuckey post-Hoc test for multiple comparisons. $\mathrm{P}$ value less than 0.05 were considered to be statistically significant (Mould, 1989).

\section{RESULTS}

I- Cerebellar cortex of 1-week old albino rat offspring:

- Cerebellar cortex of 1- week old control albino rat offspring of $\mathrm{C} 1, \mathrm{C} 2$ and $\mathrm{C3}$ (C101, C2O1 and C3O1):

Light microscopic examination of the cerebellar cortex of C1O1, C2O1 and C301 showed no significant histological differences, so their data were pooled together.
Light microscopic examination of the haematoxylin and eosin stained midsagittal sections of the cerebellar cortex of C1O1, C2O1 and C3O1 showed that the cerebellar cortex consisted of 4 layers from outside inwards; the external granular layer, the molecular layer, the Purkinje cell layer and the internal granular layer (Fig.1a). The external granular layer lied beneath the pia mater. It was formed of 10 - 14 rows of external granular cells. The superficial cells were almost closely packed together, while the 
deep cells were separated from each other. Both of them were arranged in rows perpendicular to the pia mater. They appeared rounded or oval in shape, variable in size and had deeply stained nuclei with prominent nucleoli (Figs.1a \&2a). The molecular layer was seen as a pale zone with few molecular cells. The molecular cells appeared rounded or oval in shape and had lightly stained nuclei (Fig. 2a). The Purkinje cell layer consisted of 1-2 irregular rows of Purkinje cells which appeared large, rounded or oval in shape and had large rounded vesicular nuclei with prominent nucleoli (Fig. 2a).The internal granular layer consisted of internal granular cells, which were widely separated from each other. The internal granular cells appeared rounded or oval in shape and had deeply stained nuclei with prominent nucleoli (Fig. 2a).

\section{- Cerebellar cortex of 1-week old albino rat offspring of T1 (T1O1):}

Light microscopic examination of haematoxylin and eosin stained midsagittal sections of the cerebellar cortex of T101 showed that the cerebellar cortex consisted of 4 layers from outside inwards; the external granular layer, the molecular layer, the Purkinje cell layer and the internal granular layer (Fig. 2b). The external granular layer appeared thin and ill-developed as compared to the control one. It consisted of 6-8 rows of external granular cells which were perpendicular to the pia mater. The superficial and deep cells were separated from each other. The external granular cells appeared rounded or oval in shape, variable in size and had deeply stained nuclei with prominent nucleoli. Few external granular cells appeared with irregularity in shape and others had vacuolated cytoplasm (Figs.1b \&2b) and (Figs. 1a\&2a). The molecular layer appeared thin as compared to the control one. Few molecular cells could be identified as small, irregular and deeply stained cells (Figs.1b \&2b) and (Figs. 1a\&2a). The Purkinje cell layer consisted of 1-2 irregular rows of rounded or oval Purkinje cells with rounded vesicular nuclei and prominent nuclei. Few cells appeared irregular in shape and many cells had vacuolated cytoplasm (Fig. 2b). The internal granular cells of the internal granular layer appeared widely separated from each other. They were rounded or oval in shape, variable in size and had deeply stained nuclei with prominent nucleoli. Few of them appeared irregular in shape and other cells had vacuolated cytoplasm (Fig. 2b).

- Cerebellar cortex of 1- week old albino rat offspring of T2 (T2O1):

Light microscopic examination of haematoxylin and eosin stained midsagittal sections of the cerebellar cortex of T2O1 showed that the cerebellar cortex consisted of 4 layers from outside inwards; the external granular layer, the molecular layer, the Purkinje cell layer and the internal granular layer (Fig. 1c). The external granular layer appeared thin and ill-developed as compared to the control one and T1O1. It consisted of 4-6 rows of external granular cells which were perpendicular to the pia mater. The superficial and deep cells were separated from each other. The external granular cells appeared rounded or oval in shape, variable in size and had deeply stained nuclei with prominent nucleoli. Few of them had shrunken deeply stained nuclei and some of them had vacuolated cytoplasm (Figs.1c \&2c) ; (Figs. 1a\&2a) and (Figs. 1b\&2b). The molecular layer appeared thin as compared to the control one and T101. The molecular cells could be identified as small, irregular, lightly stained cells (Figs.1c \&2c) ; (Figs. 1a\&2a) and (Figs. 1b\&2b). The Purkinje cell layer consisted of 1-2 
irregular rows of Purkinje cells which had vesicular nuclei and prominent nuclei. Some cells appeared irregular in shape and small in size (Figs. 1c \&2c). The internal granular layer consisted of widely separated internal granular cells. The cells were rounded or oval in shape, variable in size and had deeply stained nuclei with prominent nucleoli. Few of them appeared irregular in shape and other cells had vacuolated cytoplasm (Figs.1c \&2c).

\section{- Cerebellar cortex of 1-week old albino rat offspring of T3 (T3O1):}

Light microscopic examination of haematoxylin and eosin stained midsagittal sections of the cerebellar cortex of T301 showed that the cerebellar cortex consisted of 4 layers from outside inwards; the external granular layer, the molecular layer, the Purkinje cell layer and the internal granular layer (Fig.1d). The external granular layer appeared thin and ill-developed as compared to the control one and T2O1. It consisted of 3-4 rows of external granular cells which were perpendicular to the pia mater. The superficial and deep cells were separated from each other. The external granular cells appeared rounded or oval in shape, variable in size and had deeply stained nuclei with prominent nucleoli. Few nuclei appeared fragmented and some external granular cells had vacuolated cytoplasm (Figs.1d \&2d) ; (Figs. 1a\&2a) and (Figs. 1c\&2c).The molecular layer appeared as a pale zone contained molecular cells which appeared irregular in shape and had deeply stained nuclei. Few cells had shrunken deeply stained nuclei. Other cells had vacuolated cytoplasm (Figs.1d \&2d). The Purkinje cell layer consisted of one irregular row of small, irregular Purkinje cells with illdefined nuclei (Figs.1d \&2d). The internal granular layer consisted of widely separated internal granular cells.
The cells were rounded or oval in shape, variable in size and had deeply stained nuclei with prominent nucleoli. Few cells appeared irregular in shape and other cells had vacuolated cytoplasm (Figs.1d \&2d).

II- Cerebellar cortex of 2- weeks old albino rat offspring:

- Cerebellar cortex of 2-weeks old control albino rat offspring of $\mathrm{C} 1, \mathrm{C} 2$ and $\mathrm{C3}$ (C1O2, $\mathrm{C2O} 2$ and $\mathrm{C3O})$ :

Light and electron microscopic examinations of the cerebellar cortex of $\mathrm{C} 1 \mathrm{O} 2, \mathrm{C} 2 \mathrm{O} 2$ and $\mathrm{C} 3 \mathrm{O} 2$ showed no significant histological differences so their data were pooled together.

Light microscopic examination of the haematoxylin and eosin and toluidine blue stained mid-sagittal sections of the cerebellar cortex of $\mathbf{C 1 O 2}, \mathbf{C 2 O 2}$ and C3O2 showed that the cerebellar cortex consisted of four layers from outside inwards; the external granular layer, the molecular layer, the Purkinje cell layer and the internal granular layer (Fig. 3a). The external granular layer lied beneath the pia mater and consisted of 1-4 rows of external granular cells. The external granular cells were variable in size, rounded or oval in shape and had deeply stained nuclei with prominent nucleoli (Figs. 3a, 4a \&5a). The molecular layer consisted of 2 types of cells; stellate and basket. The migrating granular cells could also be seen. The stellate cells were present in the outer and middle thirds of the molecular layer. They were variable in size, oval or rounded in shape and had lightly stained nuclei with prominent nucleoli (Figs. 3a, 4a \& 5a). The basket cells were present in the deep and middle thirds of the molecular layer and in between the Purkinje cells. They were variable in size, oval or rounded in shape and had lightly stained nuclei with prominent nucleoli (Figs. 6a \& 7a). The Purkinje cells of the Purkinje cell layer 
were arranged in a single row. Most of them appeared oval in shape and some of them accepted their characteristic flask shape. They had large rounded vesicular nuclei with prominent nucleoli (Figs.3a, 6a \&7a). The internal granular layer was formed of internal granular cells which were arranged in clusters that were separated by small acidophilic areas that represent the cerebellar glomeruli. The internal granular cells were variable in size, rounded or oval in shape and had deeply stained nuclei with prominent nucleoli (Figs.3a, 6a \& 7a).

Electron microscopic examination of the cerebellar cortex of $\mathbf{C 1 O 2 , ~} \mathbf{C 2 O} 2$ and C3O2 showed that the molecular layer composed of a complex network of neuronal cells; stellate and basket cells and nerve fibers; axons and dendrites. The stellate cells had indented euchromatic nuclei with small clumps of heterochromatin, eccentric nucleoli and apparent nuclear pores. Their cytoplasm contained free ribosomes, rough and smooth endoplasmic reticula and rounded or elongated mitochondria (Fig.8a). The basket cells had indented euchromatic nuclei with small clumps of heterochromatin, apparent nuclear pores and eccentric nucleoli. Their cytoplasm contained free ribosomes, rough endoplasmic reticulum and oval mitochondria (Fig.9a). The dendrites contained mitochondria, rough endoplasmic reticulum, free ribosomes and parallel microtubules and neurofilaments. The axons contained vesicles of varying size (Figs. 8a, 9a $\boldsymbol{\&}$ 10a). The Purkinje cells had invaginated euchromatic nuclei with eccentric nucleoli and apparent nuclear pores. Their cytoplasm contained free ribosomes, rough and smooth endoplasmic reticula, and rounded or elongated mitochondria (Fig. 11a). The granular cells of the external and internal granular layers lied close together and had heterochromatic nuclei with eccentric nucleoli. Their cytoplasm contained, free ribosomes, rough endoplasmic reticulum, and small rounded or oval mitochondria (Fig. 12a).

Morphometric study of the cerebellar cortex showed insignificant difference $(\mathrm{P}$ $>0.05)$ in the means of the molecular layer thickness and the number of Purkinje cells between $\mathbf{C 1 O 2}$ and $\mathbf{C 2 O 2}$ (Table 1) and also between $\mathrm{C2O2}$ and C3O2 (Table 2).

- Cerebellar cortex of 2-weeks old albino rat offspring of $\mathrm{T} 1$ (T1O2):

Light microscopic examination of the haematoxylin and eosin and toluidine blue stained mid-sagittal sections of the cerebellar cortex of T1O2 showed that the cerebellar cortex consisted of four layers from outside inwards; the external granular layer, the molecular layer, the Purkinje cell layer and the internal granular layer (Fig. 3b). The external granular layer lied beneath the pia mater. It appeared ill-developed and consisted of 5-8 rows of external granular cells as compared to the control one. Some external granular cells appeared irregular in shape, few cells had shrunken deeply stained nuclei and areas of vacuolations could be detected (Figs. 3b, $\mathbf{4 b} \boldsymbol{\&} \mathbf{5 b}$ ) and (Figs. 3a, 4a \& 5a). Few stellate cells appeared irregular in shape and other cells had vacuolated cytoplasm. Irregular migrating granular cells could also be detected in the molecular layer (Figs. 4b \& 5b). Few basket cells appeared irregular in shape and had vacuolated cytoplasm. Some Purkinje cells appeared irregular in shape and had ill-defined outlines and nuclei. They were surrounded by areas of vacuolations (Figs. $6 \mathbf{b} \mathbf{\& 7 b}$ ). The majority of internal granular cells appeared more or less similar to the control one, but few of them appeared irregular in shape and others had 
vacuolated cytoplasm (Figs. 6b \&7b) and (Figs.6a \& 7a).

Electron microscopic examination of the cerebellar cortex of $\mathbf{C 1 O 2}, \mathbf{C 2 O} 2$ and $\mathrm{C3O2}$ showed that the molecular layer composed of a complex network of neuronal cells; stellate and basket cells and nerve fibers; axons and dendrites. The stellate cells had indented euchromatic nuclei with small clumps of heterochromatin, eccentric nucleoli and apparent nuclear pores. Their cytoplasm contained free ribosomes, rough and smooth endoplasmic reticula and rounded or elongated mitochondria (Fig.8a). The basket cells had indented euchromatic nuclei with small clumps of heterochromatin, apparent nuclear pores and eccentric nucleoli. Their cytoplasm contained free ribosomes, rough endoplasmic reticulum and oval mitochondria (Fig.9a). The dendrites contained mitochondria, rough endoplasmic reticulum, free ribosomes and parallel microtubules and neurofilaments. The axons contained vesicles of varying size (Figs. 8a, 9a $\boldsymbol{\&}$ 10a). The Purkinje cells had invaginated euchromatic nuclei with eccentric nucleoli and apparent nuclear pores. Their cytoplasm contained free ribosomes, rough and smooth endoplasmic reticula, and rounded or elongated mitochondria (Fig. 11a). The granular cells of the external and internal granular layers lied close together and had heterochromatic nuclei with eccentric nucleoli. Their cytoplasm contained, free ribosomes, rough endoplasmic reticulum, and small rounded or oval mitochondria (Fig. 12a).

Morphometric study of the cerebellar cortex showed insignificant difference (P $>0.05)$ in the means of the molecular layer thickness and the number of Purkinje cells between $\mathrm{C} 1 \mathrm{O} 2$ and $\mathrm{C} 2 \mathrm{O} 2$ (Table 1) and also between $\mathrm{C} 2 \mathrm{O} 2$ and C3O2 (Table 2).
- Cerebellar cortex of 2-weeks old albino rat offspring of $\mathrm{T} 1$ (T1O2):

Light microscopic examination of the haematoxylin and eosin and toluidine blue stained mid-sagittal sections of the cerebellar cortex of $\mathbf{T 1 O 2}$ showed that the cerebellar cortex consisted of four layers from outside inwards; the external granular layer, the molecular layer, the Purkinje cell layer and the internal granular layer (Fig. 3b). The external granular layer lied beneath the pia mater. It appeared ill-developed and consisted of 5-8 rows of external granular cells as compared to the control one. Some external granular cells appeared irregular in shape, few cells had shrunken deeply stained nuclei and areas of vacuolations could be detected (Figs. $3 b, \mathbf{4 b} \& \mathbf{5 b}$ ) and (Figs. 3a, 4a \& 5a). Few stellate cells appeared irregular in shape and other cells had vacuolated cytoplasm. Irregular migrating granular cells could also be detected in the molecular layer (Figs. 4b \& 5b). Few basket cells appeared irregular in shape and had vacuolated cytoplasm. Some Purkinje cells appeared irregular in shape and had ill-defined outlines and nuclei. They were surrounded by areas of vacuolations (Figs. $6 \mathbf{b} \mathbf{\& 7 b}$ ). The majority of internal granular cells appeared more or less similar to the control one, but few of them appeared irregular in shape and others had vacuolated cytoplasm (Figs. 6b \&7b) and (Figs.6a \& 7a).

Electron microscopic examination of the cerebellar cortex of $\mathbf{T 1 O 2}$ showed that few stellate cells appeared irregular in shape and had euchromatic nuclei with eccentric nucleoli. Their cytoplasm contained free ribosomes, rough endoplasmic reticulum, swollen mitochondria with destructed cristae and areas of undifferentiated structures (Fig. 8b). The majority of basket cells had euchromatic nuclei with eccentric 
nucleoli. Their cytoplasm contained free ribosomes, mitochondria with destructed cristae, degenerated mitochondria and few dilated rough endoplasmic reticulum (Fig. 9b). Some dendrites had few dilated rough endoplasmic reticulum, swollen mitochondria with destructed cristae and degenerated mitochondria. The axons contained vesicles of varying size (Figs. 8b, 9b \& 10b). The Purkinje cells had euchromatic nuclei. Their cytoplasm contained free ribosomes, smooth endoplasmic reticulum, numerous mitochondria with destructed cristae and few dilated rough endoplasmic reticulum (Fig.11b). The granular cells of the external and internal granular layers had heterochromatic nuclei with eccentric nucleoli. Their cytoplasm contained free ribosomes, mitochondria and rough endoplasmic reticulum within normal appearance. However, few mitochondria with destructed cristae and degenerated mitochondria could be detected (Fig. 12b).

Morphometric study of the cerebellar cortex showed significant decrease $(\mathrm{P}<0$. 05) in the means of the molecular layer thickness and the number of the Purkinje cells of T1O2 than those of $\mathbf{C 1 O 2}$ and C2O2 (Table1).

- Cerebellar cortex of 2- weeks old albino rat offspring of T2 (T2O2):

Light microscopic examination of haematoxylin and eosin and toluidine blue stained mid-sagittal sections of the cerebellar cortex of T2O2 showed that the cerebellar cortex consisted of 4 layers from outside inwards; the external granular layer, the molecular layer, the Purkinje cell layer and the internal granular layer (Fig. 3c). The external granular layer lied beneath the pia mater. It appeared ill-developed and consisted of 7-10 rows of external granular cells as compared with the control one and $\mathrm{T} 1 \mathrm{O} 2$. Some external granular cells appeared irregular in shape, few cells had vacuolated cytoplasm. Shrunken deeply stained nuclei and nuclear fragmentations were detected (Figs. 3c, 4c \& 5c); (Figs. 3a, 4a \&5a) and (Figs. 3b, 4b \& 5b). Few stellate cells appeared irregular in shape. Irregular migrating granular cells could also be detected in the molecular layer (Figs. 4c \& 5c). Many basket cells had vacuolated cytoplasm (Figs. 6c \&7c). Some Purkinje cells appeared irregular in shape and had ill-defined outlines and nuclei. They were surrounded by areas of vacuolations (Figs. 6c $87 \mathbf{c}$ ). The internal granular cells appeared scattered and didn't arrange in clusters as compared to the control one. Few cells appeared irregular in shape, others had vacuolated cytoplasm and nuclear fragmentations were detected (Figs. 6c \&7c) and (Figs. 6a \& 7a).

Electron microscopic examination of the cerebellar cortex of $\mathbf{T 2 O 2}$ showed that the stellate cells appeared oval in shape and had heterochromatic nuclei with eccentric nucleoli. Their cytoplasm contained free ribosomes, rough endoplasmic reticulum, mitochondria with destructed cristae and few degenerated mitochondria (Fig. 8c). The majority of basket cells had euchromatic nuclei. Their cytoplasm contained free ribosomes, few dilated rough endoplasmic reticulum, degenerated and swollen mitochondria with destructed cristae (Fig. 9c \&11c). Some dendrites had dilated rough endoplasmic reticulum, degenerated and swollen mitochondria with destructed cristae. The axons contained vesicles of varying size and degenerated mitochondria (Figs. 8c, 9c \& 10c). The Purkinje cells had euchromatic nuclei. Their cytoplasm contained free ribosomes, smooth endoplasmic reticulum with normal appearance, numerous swollen mitochondria with destructed cristae and few dilated rough endoplasmic reticulum 
(Fig.11c). The majority of the granular cells of the external and internal granular layers appeared more or less similar to the control one; they had heterochromatic nuclei with eccentric nucleoli, their cytoplasm contained free ribosomes, rough endoplasmic reticulum and small rounded mitochondria. However, few granular cells had euchromatic nuclei with eccentric nucleoli. Their cytoplasm contained free ribosomes, degenerated mitochondria, dilated rough endoplasmic reticulum and areas of undifferentiated structures (Fig. 12c) and (Fig. 12a).

Morphometric study of the cerebellar cortex showed significant decrease $(\mathrm{P}<0$. 05 ) in the means of the molecular layer thickness and the number of the Purkinje cells of $\mathbf{T 2 O} 2$ than those of $\mathbf{C 1 O 2}, \mathbf{C 2 O} 2$ and T1O2 (Table1).

- Cerebellar cortex of 2-weeks old albino rat offspring of $\mathrm{T3}$ (T3O2):

Light microscopic examination of haematoxylin and eosin and toluidine blue stained mid-sagittal sections of the cerebellar cortex of $\mathbf{T 3 O 2}$ showed that the cerebellar cortex consisted of 4 layers from outside inwards; the external granular layer, the molecular layer, the Purkinje cell layer and the internal granular layer (Fig. 3d). The external granular layer lied beneath the pia mater. It appeared markedly ill-developed and consisted of 10-14 rows of external granular cells as compared to the control one and T2O2. Some external granular cells appeared irregular in shape, others had vacuolated cytoplasm and nuclear fragmentation were seen (Figs. 3d, 4d, 5d \& 6d); (Figs.3a, 4a \&5a) and (Figs. 3c, $4 c$ \& 5c). Some stellate cells appeared irregular in shape (Figs. 4d, 5d \& 6d). Few basket cells appeared irregular in shape and others had vacuolated cytoplasm (Figs. $\quad 6 d \quad \mathbf{\& 7 d}$ ). Some Purkinje cells appeared irregular in shape and had ill-defined outlines and nuclei.
Other cells were mall-oriented whereas, their long axes were parallel to the pia mater. They were surrounded by areas of vacuolations (Figs. 6d \&7d). The internal granular cells appeared scattered and didn't arrange in clusters as compared to the control one. Few cells appeared irregular in shape (Figs. 6d \& 7d) and (Figs. 6a \&7a).

Electron microscopic examination of the cerebellar cortex of $\mathbf{T 3 O 2}$ showed that some stellate cells had heterochromatic nuclei with eccentric nucleoli. Their cytoplasm contained free ribosomes, dilated rough endoplasmic reticulum, degenerated and swollen mitochondria with destructed cristae (Fig. 8d). The majority of basket cells had euchromatic nuclei. Their cytoplasm contained free ribosomes, few dilated rough endoplasmic reticulum, areas of undifferentiated structures, degenerated and swollen mitochondria with destructed cristae (Fig. 9d \& 11d). The dendrites had mitochondria with destructed cristae, degenerated mitochondria and numerous dilated rough endoplasmic reticulum. The axons contained vesicles of varying size (Figs. 8d, 9d \& 10d). Some Purkinje cells appeared irregular in shape and shrunken. Their cytoplasmic organelles could not be differentiated easily. However, numerous dilated rough endoplasmic reticulum could only be differentiated (Fig.11d). Some granular cells of external and internal granular layers had irregular, shrunken nuclei with condensed clumps of heterochromatin. Other cells had heterochromatic nuclei with eccentric nucleoli and their cytoplasm contained free ribosomes, swollen mitochondria with destructed cristae, few dilated rough endoplasmic reticulum and area of undifferentiated structures (Fig. 12d).

Morphometric study of the cerebellar cortex showed significant decrease in the 
means of the molecular layer thickness and the Purkinje cell number of T3O2 than those of $\mathbf{C 2 O 2}, \mathbf{C 3 O 2}$ and $\mathbf{T 2 O 2}$

(Table2).

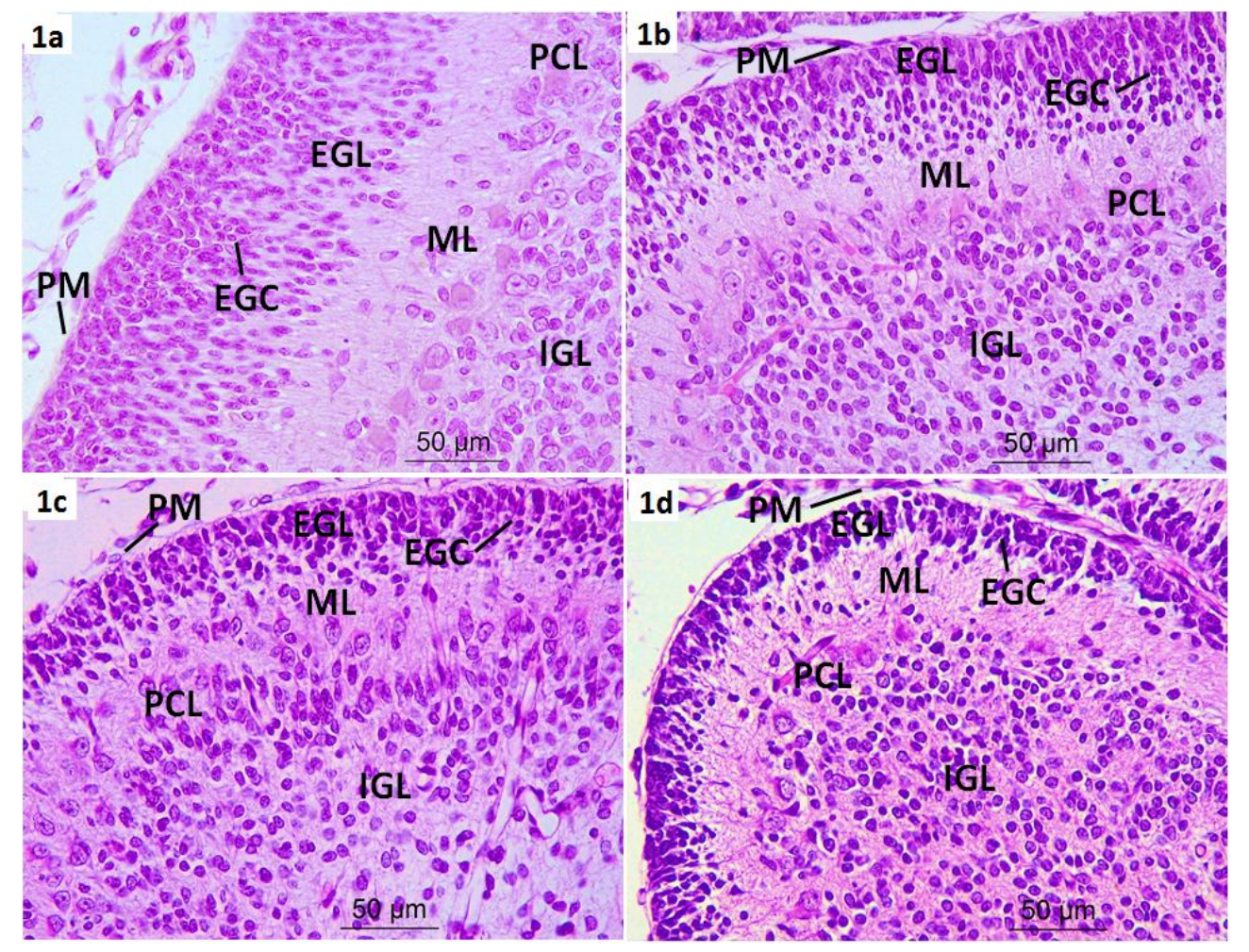

Fig. (1a): A photomicrograph of a median sagittal section of the cerebellar cortex of C1O1, C2O1 and $\mathrm{C} 3 \mathrm{O} 1$ showed that the cerebellar cortex consisted of external granular layer (EGL), molecular layer (ML), Purkinje cell layer (PCL) and internal granular layer (IGL). The external granular layer lied beneath the pia mater $(\mathbf{P M})$ and consisted of $10-14$ rows of external granular cells (EGC) (H \& E X 400).

Fig. (1b): A photomicrograph of a median sagittal section of the cerebellar cortex of T1O1 showed that the cerebellar cortex consisted of external granular layer (EGL), molecular layer (ML), Purkinje cell layer (PCL) and internal granular layer (IGL). The external granular layer lied beneath the pia mater (PM) and consisted of 6-8 rows of external granular cells (EGC) (H \& $\mathbf{E}$ $\mathrm{X}$ 400).

Fig. (1c): A photomicrograph of a median sagittal section of the cerebellar cortex of T2O1 showed that the cerebellar cortex consisted of external granular layer (EGL), molecular layer (ML), Purkinje cell layer (PCL) and internal granular layer (IGL). The external granular layer lied beneath the pia mater (PM) and consisted of 4-6 rows of external granular cells (EGC) $(\mathbf{H} \& \mathbf{E}$ $\mathrm{X}$ 400).

Fig. (1d): A photomicrograph of a median sagittal section of the cerebellar cortex of T3O1 showed that the cerebellar cortex consisted of external granular layer (EGL), molecular layer (ML), Purkinje cell layer (PCL) and internal granular layer (IGL). The external granular layer lied beneath the pia mater (PM) and consisted of 3-4 rows of external granular cells (EGC) (H \& E $\mathrm{X}$ 400). 


\section{Effect of fluoxetine hydrochloride on the histological ...}

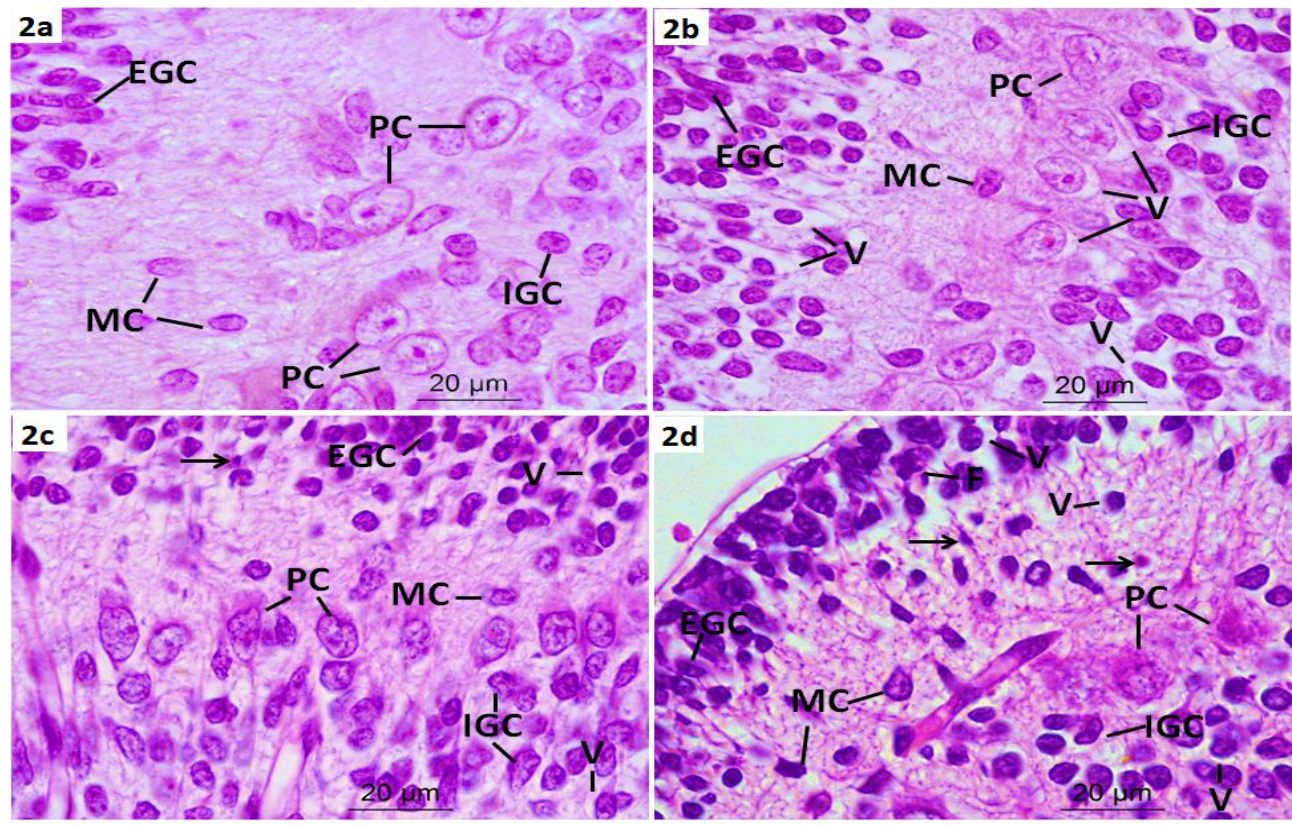

Fig. (2a): A photomicrograph of a median sagittal section of the cerebellar cortex of C1O1, C2O1 and $\mathrm{C} 3 \mathrm{O} 1$ showed that the external granular cells (EGC) appeared rounded or oval in shape, variable in size and had deeply stained nuclei with prominent nucleoli. The molecular cells (MC) were rounded or oval in shape and had lightly stained nuclei. The Purkinje cells (PC) arranged in 1-2 irregular rows, they were large, nearly rounded or oval in shape and had large rounded or oval vesicular nuclei with prominent nucleoli. The internal granular cells (IGC) were widely separated from each other and appeared rounded or oval in shape and had deeply stained nuclei with prominent nucleoli (H \& E X 1000).

Fig. (2b): A photomicrograph of a median sagittal section of the cerebellar cortex of T1O1 showed that few external granular cells (EGC) appeared with irregularity in shape and others had vacuolated cytoplasm (V). The molecular cells (MC) were small, irregular in shape and deeply stained. Few Purkinje cells (PC) were irregular in shape, and others had vacuolated cytoplasm (V). Few internal granular cells (IGC) were irregular in shape, and others had vacuolated cytoplasm (V) (H \& E X 1000).

Fig. (2c): A photomicrograph of a median sagittal section of the cerebellar cortex of T2O1 showed that the external granular cells (EGC) appeared rounded or oval in shape, variable in size and had deeply stained nuclei with prominent nucleoli. Few of them had shrunken deeply stained nuclei $(\rightarrow)$, and others had vacuolated cytoplasm (V). The molecular cells (MC) were irregular in shape. The Purkinje cells (PC) appeared irregular in shape and small in size. Few internal granular cells (IGC) were irregular in shape, and others had vacuolated cytoplasm (V) (H \& E X 1000).

Fig. (2d): A photomicrograph of a median sagittal section of the cerebellar cortex of T3O1 showed that the external granular cells (EGC) appeared rounded or oval in shape, variable in size and had deeply stained nuclei with prominent nucleoli. Few of them had fragmented nuclei (F), and others had vacuolated cytoplasm (V). The molecular cells (MC) were irregular in shape. Few cells had shrunken deeply stained nuclei $(\rightarrow)$, and others had vacuolated cytoplasm (V). The Purkinje cells (PC) appeared small and irregular in shape with ill-defined nuclei. Few internal granular cells (IGC) were irregular in shape, and others had vacuolated cytoplasm (V)(H \& E X 1000). 

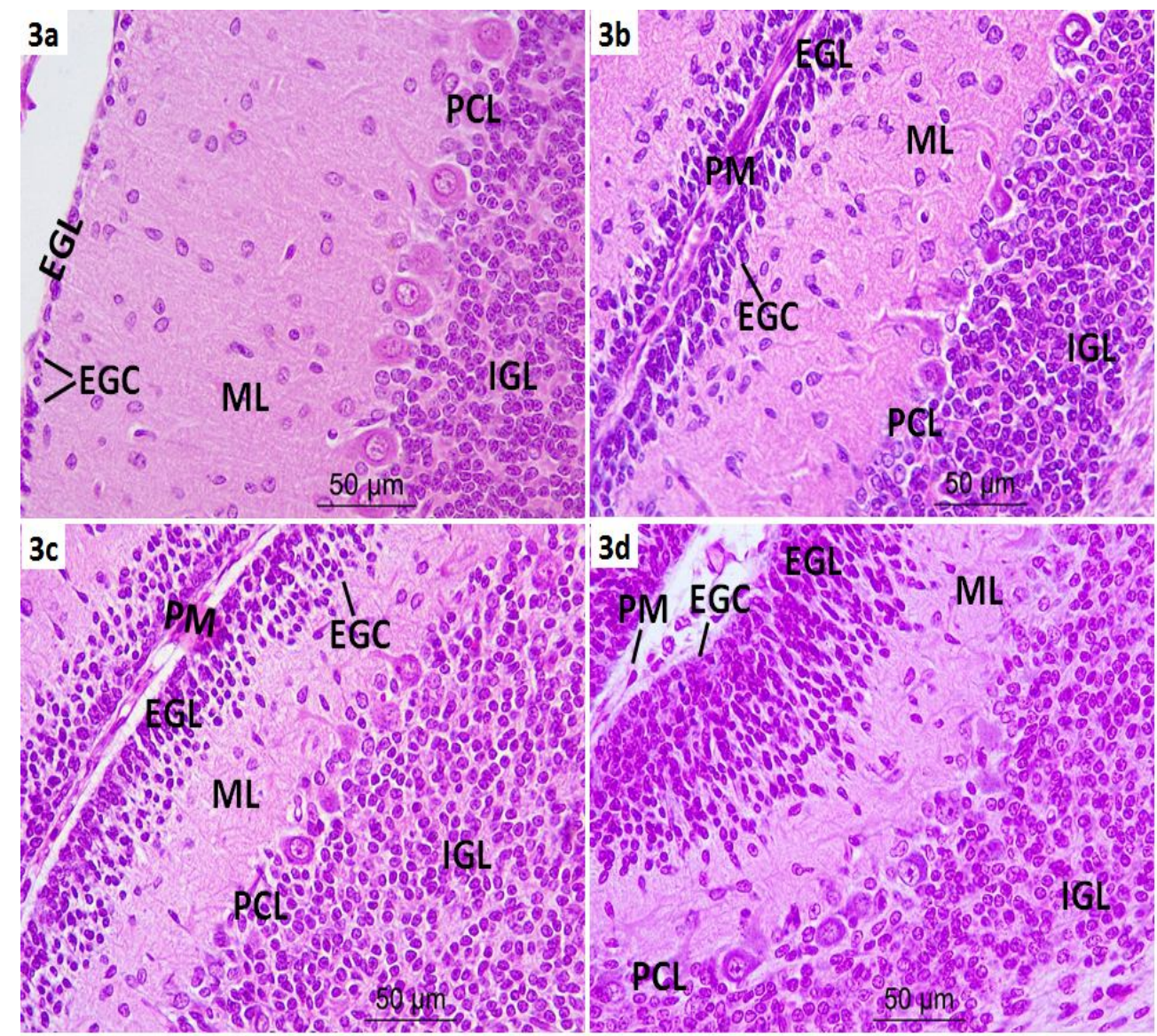

Fig. (3a): A photomicrograph of a median sagittal section of the cerebellar cortex of $\mathrm{C} 1 \mathrm{O} 2, \mathrm{C} 2 \mathrm{O} 2$ and $\mathrm{C} 3 \mathrm{O} 2$ showed that the cerebellar cortex consisted of external granular layer (EGL), molecular layer (ML), Purkinje cell layer (PCL) and internal granular layer (IGL). The external granular layer lied beneath the pia mater (PM) and consisted of 1-2 rows of external granular cells (EGC) (H \& E X 400).

Fig. (3b): A photomicrograph of a median sagittal section of the cerebellar cortex of T1O2 showed that the cerebellar cortex consisted of external granular layer (EGL), molecular layer (ML), Purkinje cell layer (PCL) and internal granular layer (IGL). The external granular layer lied beneath the pia mater (PM) and consisted of 5-6 rows of external granular cells (EGC) (H \& E X 400).

Fig. (3c): A photomicrograph of a median sagittal section of the cerebellar cortex of T2O2 showed that the cerebellar cortex consisted of external granular layer (EGL), molecular layer (ML), Purkinje cell layer (PCL) and internal granular layer (IGL). The external granular layer lied beneath the pia mater (PM) and consisted of 7-10 rows of external granular cells (EGC) (H \& E $\mathrm{X}$ 400).

Fig. (3d): A photomicrograph of a median sagittal section of the cerebellar cortex of $\mathrm{T} 3 \mathrm{O} 2$ showed that the cerebellar cortex consisted of external granular layer (EGL), molecular layer (ML), Purkinje cell layer (PCL) and internal granular layer (IGL). The external granular layer lied beneath the pia mater (PM) and consisted of $10-14$ rows of external granular cells (EGC) (H \& E X 400). 


\section{Effect of fluoxetine hydrochloride on the histological ...}
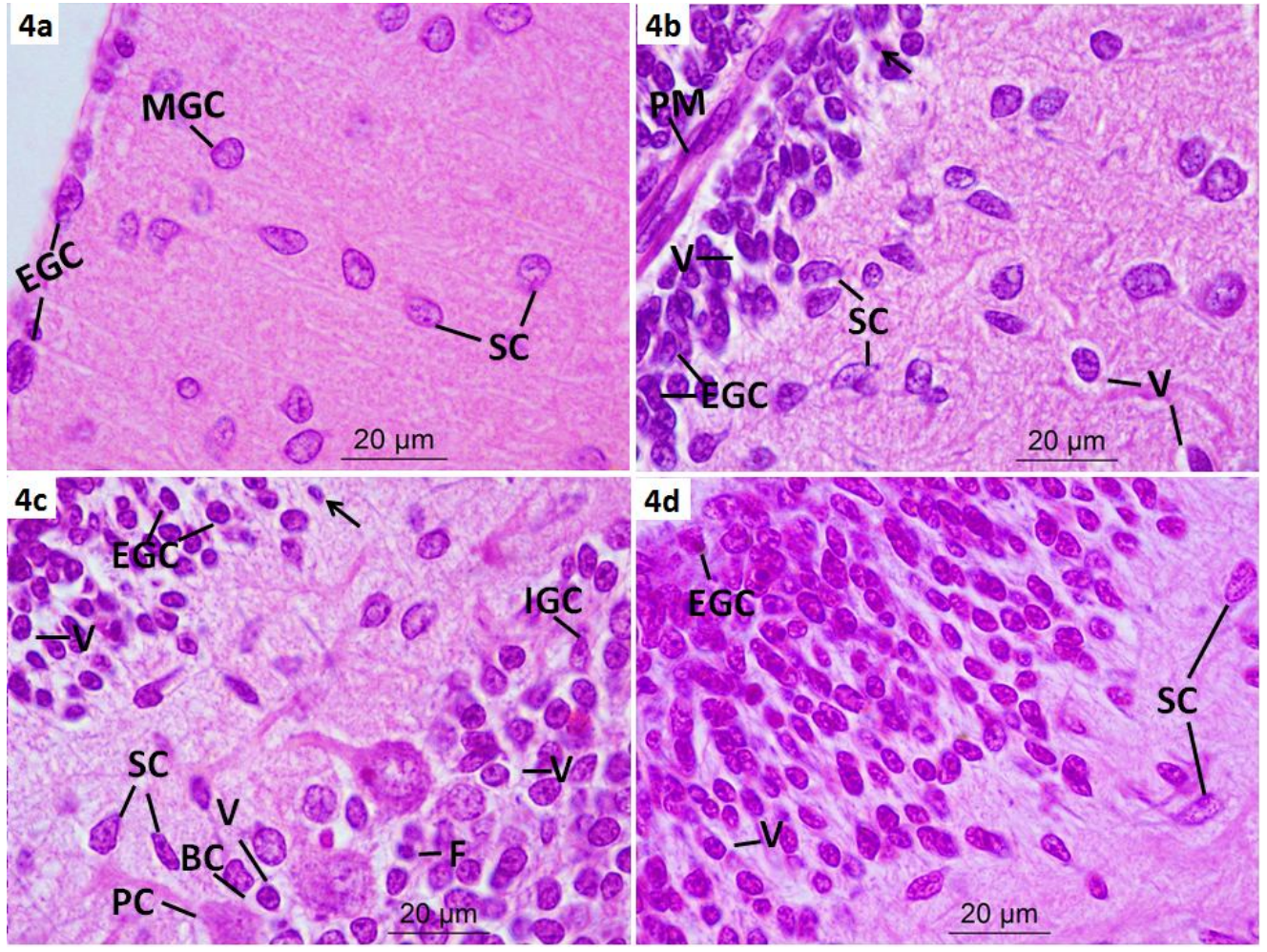

Fig. (4a): A photomicrograph of a median sagittal section of the upper part of the cerebellar cortex of $\mathrm{C} 1 \mathrm{O} 2, \mathrm{C} 2 \mathrm{O} 2$ and $\mathrm{C} 3 \mathrm{O} 2$ showed that the external granular cells (EGC) were variable in size, rounded or oval in shape and had deeply stained nuclei with prominent nucleoli. The stellate cells (SC) were variable in size, oval or rounded in shape and had lightly stained nuclei with prominent nucleoli. Migrating granular cells (MGC) were present (H \& E X 1000).

Fig. (4b): A photomicrograph of a median sagittal section of the upper part of the cerebellar cortex of T1O2 showed the pia mater (PM). Few external granular cells (EGC) appeared irregular in shape, and few cells had shrunken deeply stained nuclei $(\rightarrow)$.Other cells were surrounded by areas of vacuolations (V). Few stellate cells (SC) appeared irregular in shape, and others had vacuolated cytoplasm (V) (H \& E X 1000).

Fig. (4c): A photomicrograph of a median sagittal section of the cerebellar cortex of $\mathrm{T} 2 \mathrm{O} 2$ showed that some external granular cells (EGC) appeared irregular in shape, and others had vacuolated cytoplasm (V). Few of them have shrunken deeply stained nuclei $(\rightarrow)$. Few stellate cells (SC) appeared irregular in shape. Few basket cells (BC) had vacuolated cytoplasm (V). Some Purkinje cells (PC) appeared irregular in shape and had ill-defined outlines and nuclei. Few internal granular cells (IGC) were irregular in shape and others had vacuolated cytoplasm (V) and nuclear fragmentations (F) (H \& E X 1000).

Fig.(4d): A photomicrograph of a median sagittal section of the upper part of the cerebellar cortex of $\mathrm{T} 3 \mathrm{O} 2$ showed that some external granular cells (EGC) appeared irregular in shape, and others had vacuolated cytoplasm (V). Few stellate cells (SC) were irregular in shape (H \& E X 1000). 

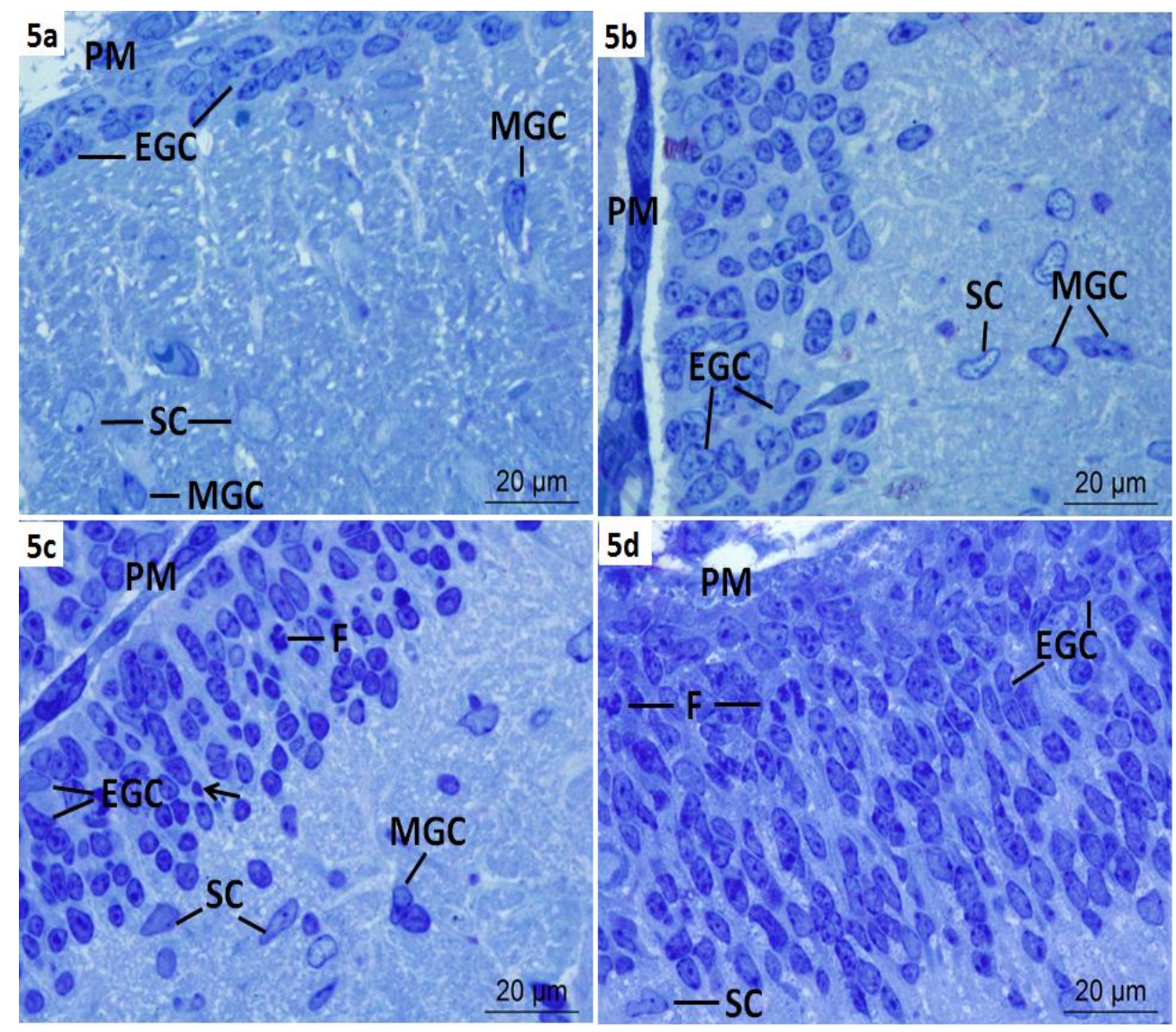

Fig. (5a): A photomicrograph of a median sagittal section of the upper part of the cerebellar cortex of $\mathrm{C} 1 \mathrm{O} 2, \mathrm{C} 2 \mathrm{O} 2$ and $\mathrm{C} 3 \mathrm{O} 2$ showed that the external granular cells (EGC) lied beneath the pia mater (PM). They arranged in 3-4 rows and appeared rounded or oval in shape and had deeply stained nuclei with prominent nucleoli. The stellate cells (SC) were variable in size, oval or rounded in shape, and had lightly stained nuclei with prominent nucleoli. Migrating granular cells (MGC) were present (Toluidine blue X 1000).

Fig. (5b): A photomicrograph of a median sagittal section of the upper part of the cerebellar cortex of $\mathrm{T} 1 \mathrm{O} 2$ showed that the external granular cells (EGC) lied beneath the pia mater (PM) and arranged in 6-8 rows, and some of them appeared irregular in shape. Few stellate cells (SC) were irregular in shape. Irregular migrating granular cells (MGC) were noticed (Toluidine blue X 1000).

Fig. (5c): A photomicrograph of a median sagittal section of the upper part of the cerebellar cortex of T2O2 showed that the external granular cells (EGC) lied beneath the pia mater (PM) and arranged in 7-10 rows, and some of them appeared irregular in shape. Few of them had shrunken deeply stained nuclei $(\rightarrow)$, and nuclear fragmentations $(F)$ were present. The stellate cells (SC) appeared irregular in shape. Irregular migrating granular cells (MGC) were noticed (Toluidine blue X 1000).

Fig. (5d): A photomicrograph of a median sagittal section of the upper part of the cerebellar cortex of $\mathrm{T} 3 \mathrm{O} 2$ showed that the external granular cells lied beneath the pia mater (PM) and arranged in 10-14 rows. Some of them appeared irregular in shape (EGC), and others had fragmented nuclei (F). Few stellate cells (SC) appeared irregular in shape (Toluidine blue X 1000). 


\section{Effect of fluoxetine hydrochloride on the histological ...}

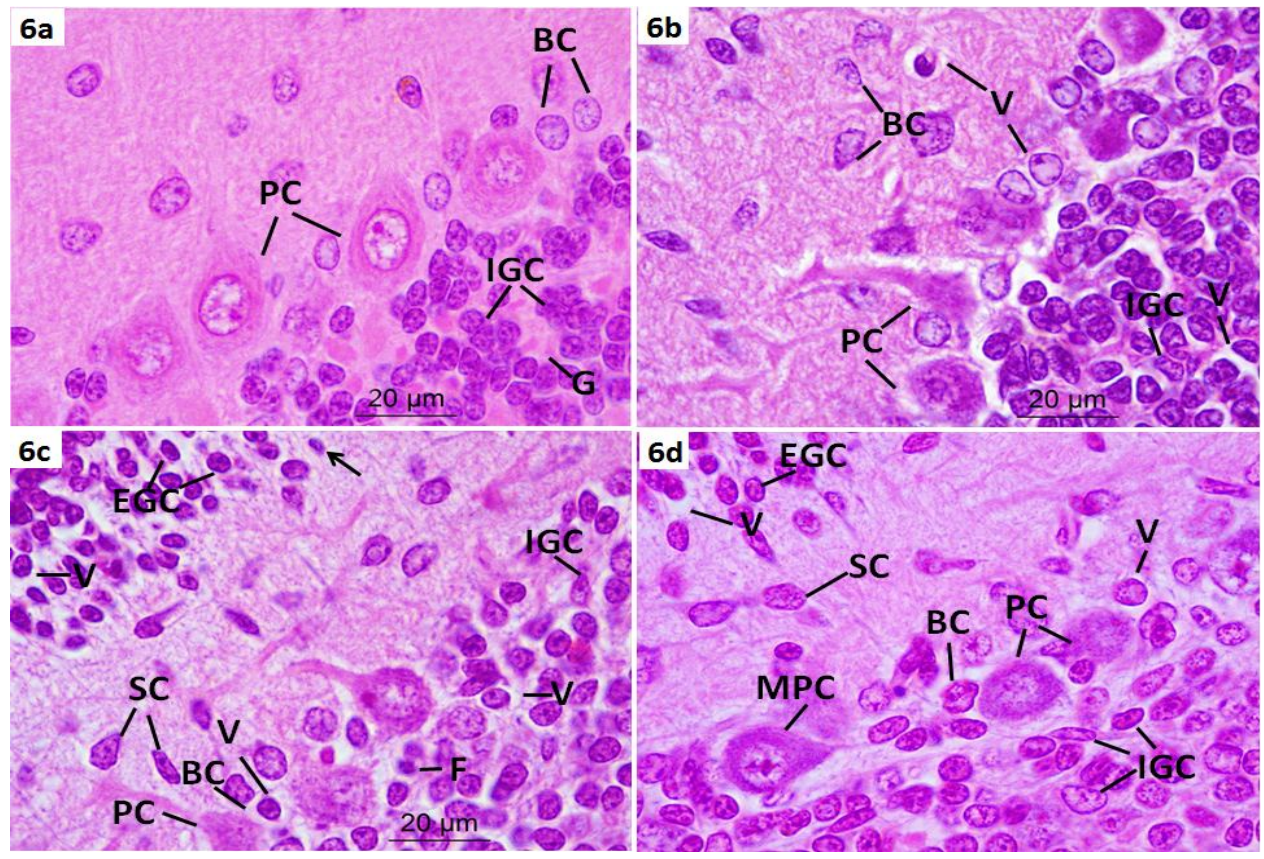

Fig. (6a): A photomicrograph of a median sagittal section of the lower part of the cerebellar cortex of $\mathrm{C} 1 \mathrm{O} 2, \mathrm{C} 2 \mathrm{O} 2$ and $\mathrm{C} 3 \mathrm{O} 2$ showed that the basket cells (BC) appeared oval or rounded in shape and had lightly stained nuclei with prominent nucleoli. The Purkinje cells (PC) appeared oval or flask shape and had large rounded vesicular nuclei with prominent nucleoli. The internal granular cells (IGC) arranged in clusters that were separated by the cerebellar glomeruli (G). They appeared rounded or oval in shape and had deeply stained nuclei with prominent nucleoli (H \& E X 1000).

Fig. (6b): A photomicrograph of a median sagittal section of the lower part of the cerebellar cortex of $\mathrm{T} 1 \mathrm{O} 2$ showed that few basket cells (BC) appeared irregular in shape, and others had vacuolated cytoplasm (V). Some Purkinje cells (PC) were irregular in shape and had ill-defined outlines and nuclei and were surrounded by areas of vacuolations. Few internal granular cells (IGC) appeared irregular in shape, and others had vacuolated cytoplasm (V) (H \& E X 1000).

Fig. (6c): A photomicrograph of a median sagittal section of the cerebellar cortex of $\mathrm{T} 2 \mathrm{O} 2$ showed that some external granular cells (EGC) appeared irregular in shape, and others had vacuolated cytoplasm $(\mathrm{V})$. Few of them had shrunken deeply stained nuclei $(\rightarrow)$. Few stellate cells (SC) appeared irregular in shape. Few basket cells (BC) had vacuolated cytoplasm (V). Some Purkinje cells (PC) were irregular in shape and had ill-defined outlines and nuclei. The internal granular cells appeared scattered, and few of them (IGC) were irregular in shape, and others had vacuolated cytoplasm (V), and nuclear fragmentations (F) were noticed (H \& E X 1000).

Fig. (6d): A photomicrograph of a median sagittal section of the cerebellar cortex of $\mathrm{T} 3 \mathrm{O} 2$ showed that many external granular cells (EGC) had normal appearance. Other cells had vacuolated cytoplasm (V). Few stellate cells (SC) appeared irregular in shape. Few basket cells (BC) appeared irregular in shape, and others had vacuolated cytoplasm (V). Some Purkinje cells (PC) appeared irregular in shape and had ill-defined outlines and nuclei. Others appeared malloriented (MPC), and they were surrounded by areas of vacuolations. The internal granular cells appeared scattered, and few of them (IGC) were irregular in shape (H \& E X 1000). 

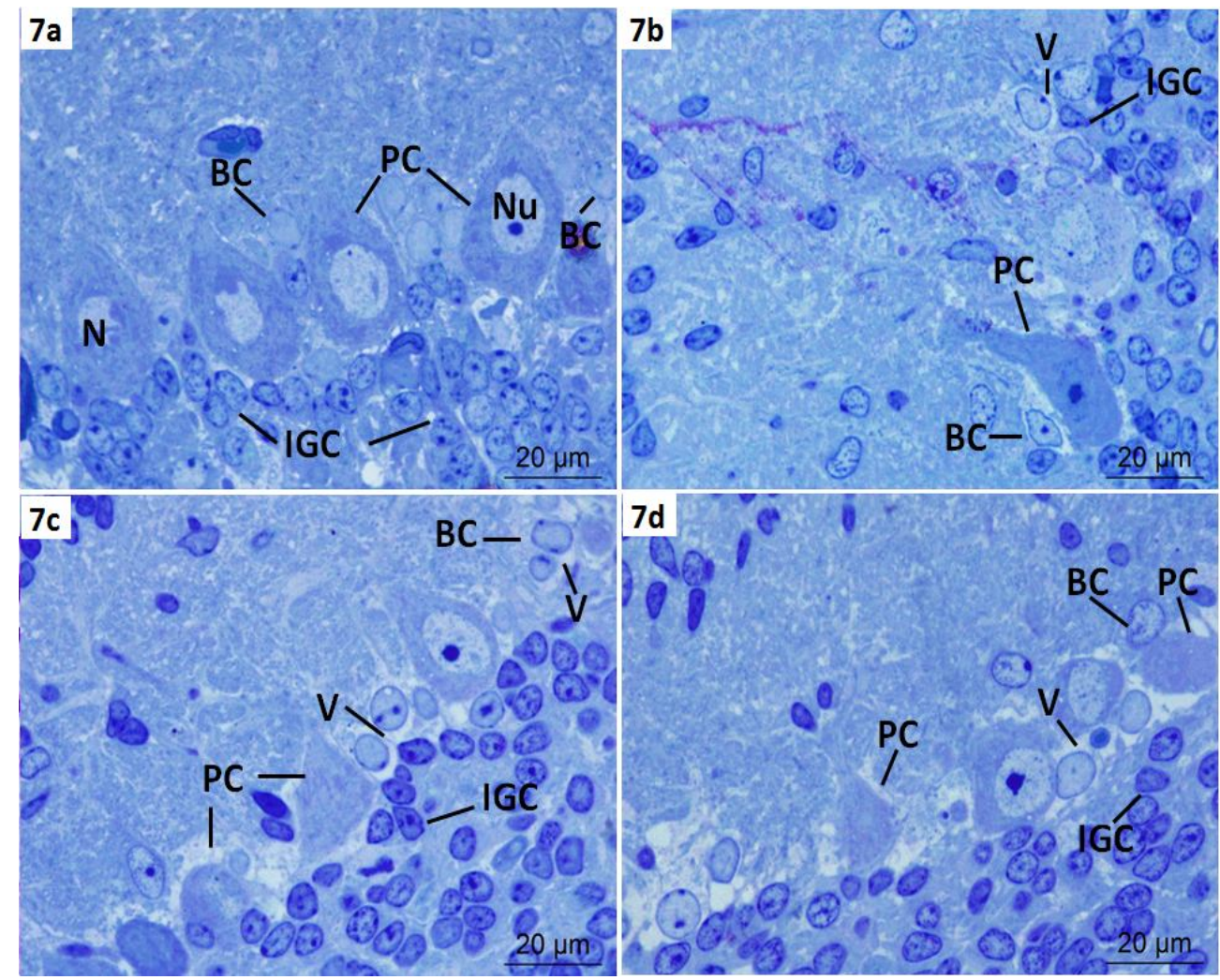

Fig. (7a): A photomicrograph of a median sagittal section of the lower part of the cerebellar cortex of $\mathrm{C} 1 \mathrm{O} 2, \mathrm{C} 2 \mathrm{O} 2$ and $\mathrm{C} 3 \mathrm{O} 2$ showed that the basket cells (BC) appeared oval or rounded in shape and had lightly stained nuclei with prominent nucleoli. The Purkinje cells (PC) appeared oval or flask shape, and had large rounded vesicular nuclei $(\mathrm{N})$ with prominent nucleoli $(\mathrm{Nu})$. The internal granular cells (IGC) arranged in clusters. They appeared rounded or oval in shape and had deeply stained nuclei with prominent nucleoli (Toluidine blue X 1000).

Fig. (7b): A photomicrograph of a median sagittal section of the lower part of the cerebellar cortex of $\mathrm{T} 1 \mathrm{O} 2$ showed that few basket cells (BC) appeared irregular in shape, and others had vacuolated cytoplasm (V). Some Purkinje cells (PC) were irregular in shape and had ill-defined outlines, and were surrounded by areas of vacuolations. Few internal granular cells (IGC) appeared irregular in shape (Toluidine blue X 1000).

Fig. (7c): A photomicrograph of a median sagittal section of the lower part of the cerebellar cortex of $\mathrm{T} 2 \mathrm{O} 2$ showed that few basket cells (BC) appeared irregular in shape, and others had vacuolated cytoplasm (V). Some Purkinje cells (PC) were irregular in shape and had ill-defined outlines and nuclei, and they were surrounded by areas of vacuolations. Few internal granular cells (IGC) appeared irregular in shape (Toluidine blue X 1000).

Fig. (7d): A photomicrograph of a median sagittal section of the lower part of the cerebellar cortex of $\mathrm{T} 3 \mathrm{O} 2$ showed that few basket cells (BC) appeared with irregularity in shape, and others had vacuolated cytoplasm (V). Some Purkinje cells (PC) appeared irregular in shape and had illdefined outlines and nuclei, and they were surrounded by areas of vacuolations. Few internal granular cells (IGC) appeared irregular in shape (Toluidine blue X 1000). 


\section{Effect of fluoxetine hydrochloride on the histological ...}
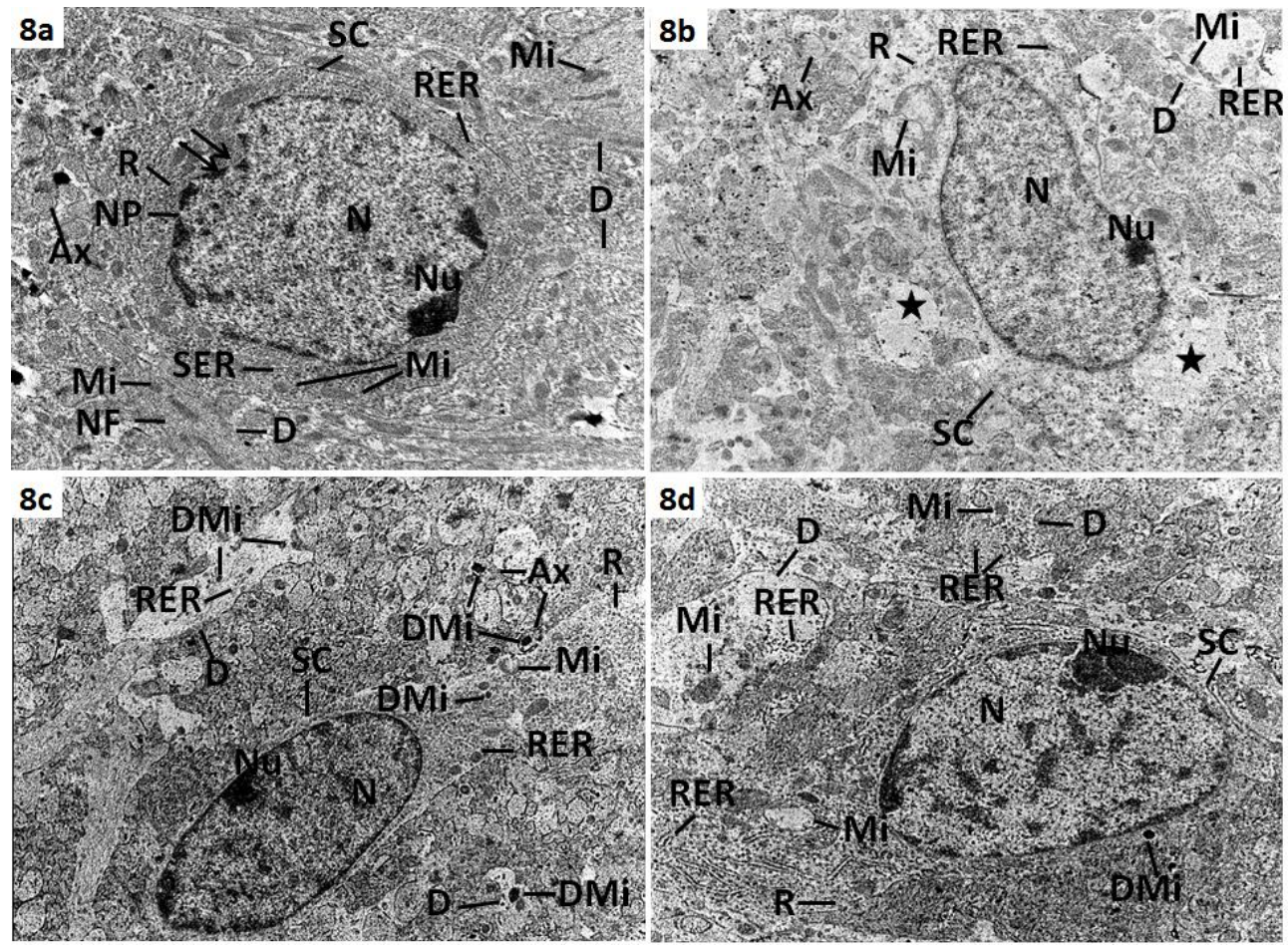

Fig. (8a): An electron micrograph of the molecular layer of $\mathrm{C} 1 \mathrm{O} 2, \mathrm{C} 2 \mathrm{O} 2$ and $\mathrm{C} 3 \mathrm{O} 2$ showed that the stellate cell (SC) had indented (2 arrows) euchromatic nucleus $(\mathrm{N})$ with small clumps of heterochromatin with eccentric nucleoli $(\mathrm{Nu})$ and apparent nuclear pores (NP). Its cytoplasm contained free ribosomes (R), rough (RER) and smooth endoplasmic reticula (SER) and rounded or elongated mitochondria (Mi). Axons (Ax) and dendrites (D) were present. The dendrites contained mitochondria (Mi) and parallel microtubules and neurofilaments (NF)(TEM X 10000).

Fig. (8b): An electron micrograph of the molecular layer of $\mathrm{T} 1 \mathrm{O} 2$ showed that the stellate cell (SC) appeared irregular in shape and had euchromatic nucleus $(\mathrm{N})$ with eccentric nucleolus $(\mathrm{Nu})$. Its cytoplasm contained free ribosomes (R), rough endoplasmic reticulum (RER) with normal appearance, mitochondria with destructed cristae (Mi), and areas of undifferentiated structures (Star). Axons (Ax) and dendrites (D) were present. The dendrites contained mitochondria (Mi) and rough endoplasmic reticulum (RER) with normal appearance (TEM X 10000).

Fig. (8c): An electron micrograph of the molecular layer of $\mathrm{T} 2 \mathrm{O} 2$ showed that the stellate cell (SC) had heterochromatic nucleus $(\mathrm{N})$ with eccentric nucleolus $(\mathrm{Nu})$. Its cytoplasm contained free ribosomes $(\mathrm{R})$, mitochondria with destructed cristae (Mi), degenerated mitochondria (DMi) and rough endoplasmic reticulum (RER) with normal appearance. Axons (Ax) were present and contained degenerated mitochondria (DMi). Dendrites (D) were also present and contained degenerated mitochondria (DMi) and rough endoplasmic reticulum (RER) with normal appearance (TEM X 10000).

Fig. (8d): An electron micrograph of the molecular layer of $\mathrm{T} 3 \mathrm{O} 2$ showed that the stellate cell (SC) had heterochromatic nucleus $(\mathrm{N})$ with eccentric nucleolus $(\mathrm{Nu})$. Its cytoplasm contained free ribosomes (R), dilated rough endoplasmic reticulum (RER), degenerated (DMi) and swollen mitochondria with destructed cristae (Mi). Dendrites (D) were present and contained dilated rough endoplasmic reticulum (RER) and mitochondria (Mi) with normal appearance (TEM X 10000). 

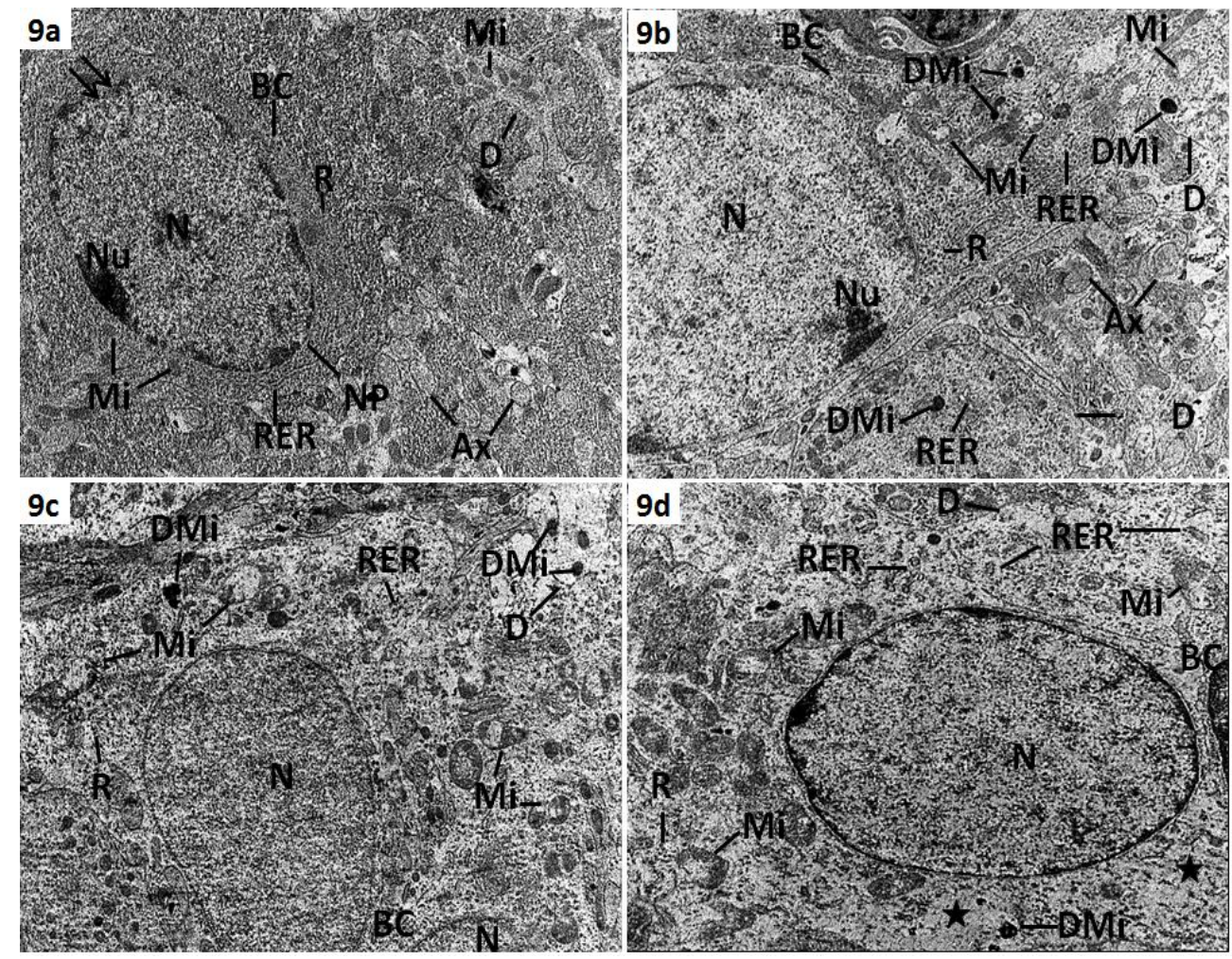

Fig. (9a): An electron micrograph of the molecular layer of $\mathrm{C} 1 \mathrm{O} 2, \mathrm{C} 2 \mathrm{O} 2$ and $\mathrm{C} 3 \mathrm{O} 2$ showed that the basket cell (BC) had indented (2 arrows) euchromatic nucleus (N) with small clumps of heterochromatin, apparent nuclear pores (NP) and eccentric nucleolus (Nu). Its cytoplasm contained free ribosomes (R), rough endoplasmic reticulum (RER) and rounded or elongated mitochondria (Mi). Axons (Ax) and dendrites (D) were present. The dendrites contained numerous rounded or oval mitochondria (Mi) (TEM X 10000).

Fig. (9b): An electron micrograph of the molecular layer of T1O2 showed that the basket cell (BC) had euchromatic nucleus $(\mathrm{N})$ and eccentric nucleolus $(\mathrm{Nu})$. Its cytoplasm contained free ribosomes $(\mathrm{R})$, few dilated rough endoplasmic reticulum (RER), degenerated (DMi) and swollen mitochondria with destructed cristae (Mi). Axons (Ax) and dendrites (D) were present. The dendrites had few dilated rough endoplasmic reticulum (RER), mitochondria with destructed cristae (Mi) and degenerated mitochondria (DMi) (TEM X 10000).

Fig. (9c): An electron micrograph of the molecular layer of T2O2 showed that the basket cells (BC) had euchromatic nuclei $(\mathrm{N})$. Their cytoplasm contained free ribosomes $(\mathrm{R})$, few dilated rough endoplasmic reticulum (RER), degenerated (DMi) and swollen mitochondria with destructed cristae (Mi). Dendrites (D) were present and contained degenerated mitochondria (DMi) (TEM $\mathrm{X}$ 10000).

Fig. (9d): An electron micrograph of the molecular layer of $\mathrm{T} 3 \mathrm{O} 2$ showed that the basket cell (BC) had euchromatic nucleus $(\mathrm{N})$. Its cytoplasm contained free ribosomes $(\mathrm{R})$, few dilated rough endoplasmic reticulum (RER), areas of undifferentiated structures (Star), degenerated (DMi) and swollen mitochondria with destructed cristae (Mi). Dendrites (D) were present and contained swollen mitochondria with destructed cristae (Mi) and dilated rough endoplasmic reticulum (RER) (TEM X 10000). 


\section{Effect of fluoxetine hydrochloride on the histological ...}

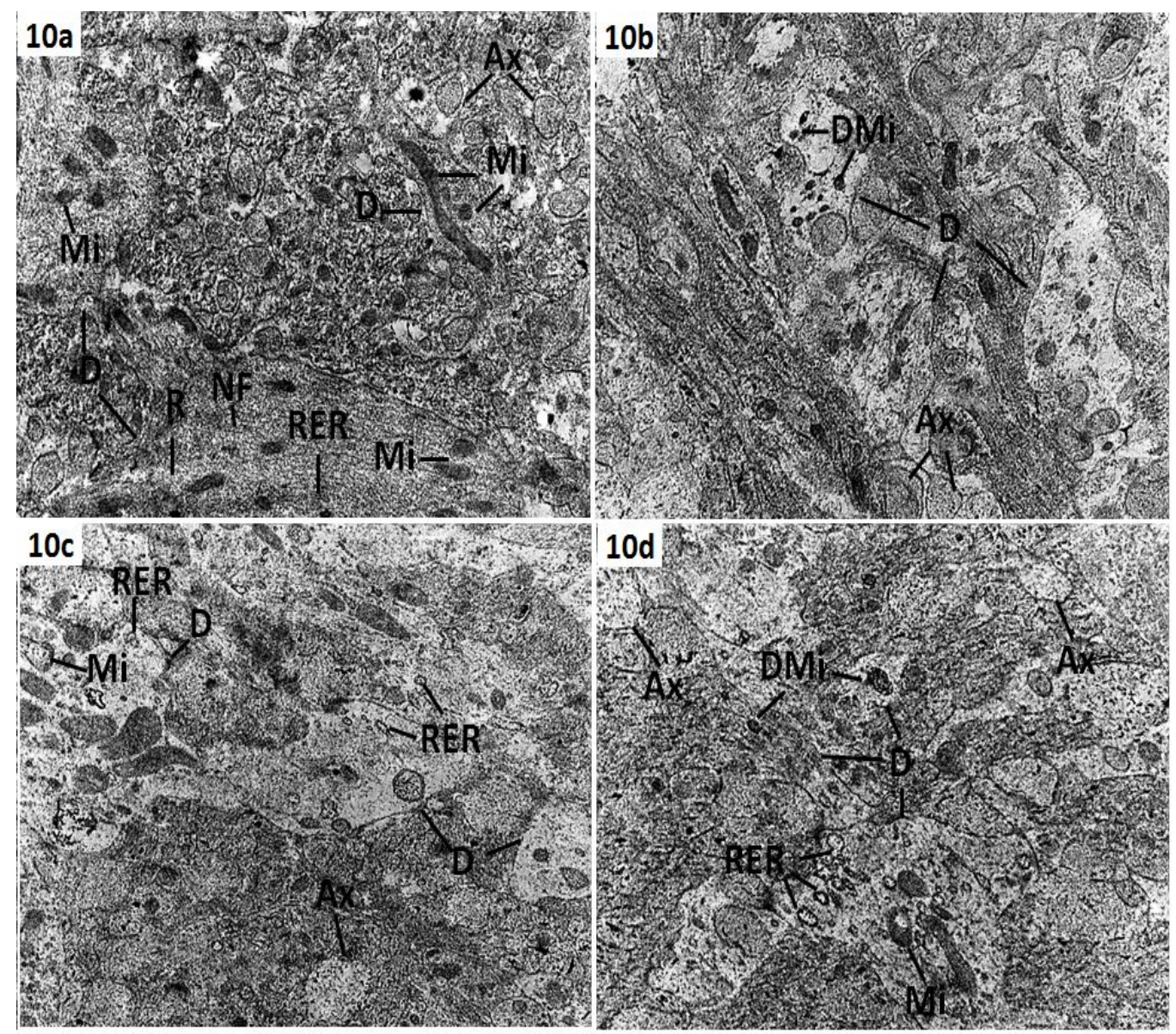

Fig. (10a): An electron micrograph of the neuropil of the molecular layer of C1O2, C2O2 and $\mathrm{C} 3 \mathrm{O} 2$ showed that the axons (Ax) contained vesicles of varying size. The dendrites (D) contained mitochondria (Mi), rough endoplasmic reticulum (RER), free ribosomes (R) and parallel microtubules and neurofilaments (NF) (TEM X 10000).

Fig. (10b): An electron micrograph of the neuropil of the molecular layer of $\mathrm{T} 1 \mathrm{O} 2$ showed that some dendrites (D) contained degenerated mitochondria (DMi). The axons (Ax) contained vesicles of varying size (TEM $X$ 10000).

Fig. (10c): An electron micrograph of the neuropil of the molecular layer of $\mathrm{T} 2 \mathrm{O} 2$ showed that some dendrites (D) contained swollen mitochondria with destructed cristae (Mi) and dilated rough endoplasmic reticulum (RER). The axons $(\mathrm{Ax})$ contained vesicles of varying size (TEM $\mathrm{X} 10000)$

Fig. (10d): An electron micrograph of the neuropil of the molecular layer of $\mathrm{T} 3 \mathrm{O} 2$ showed that some dendrites (D) contained numerous dilated rough endoplasmic reticula (RER), degenerated (DMi) and swollen mitochondria with destructed cristae (Mi), The axons (Ax) contained vesicles of varying size(TEM $X$ 10000). 

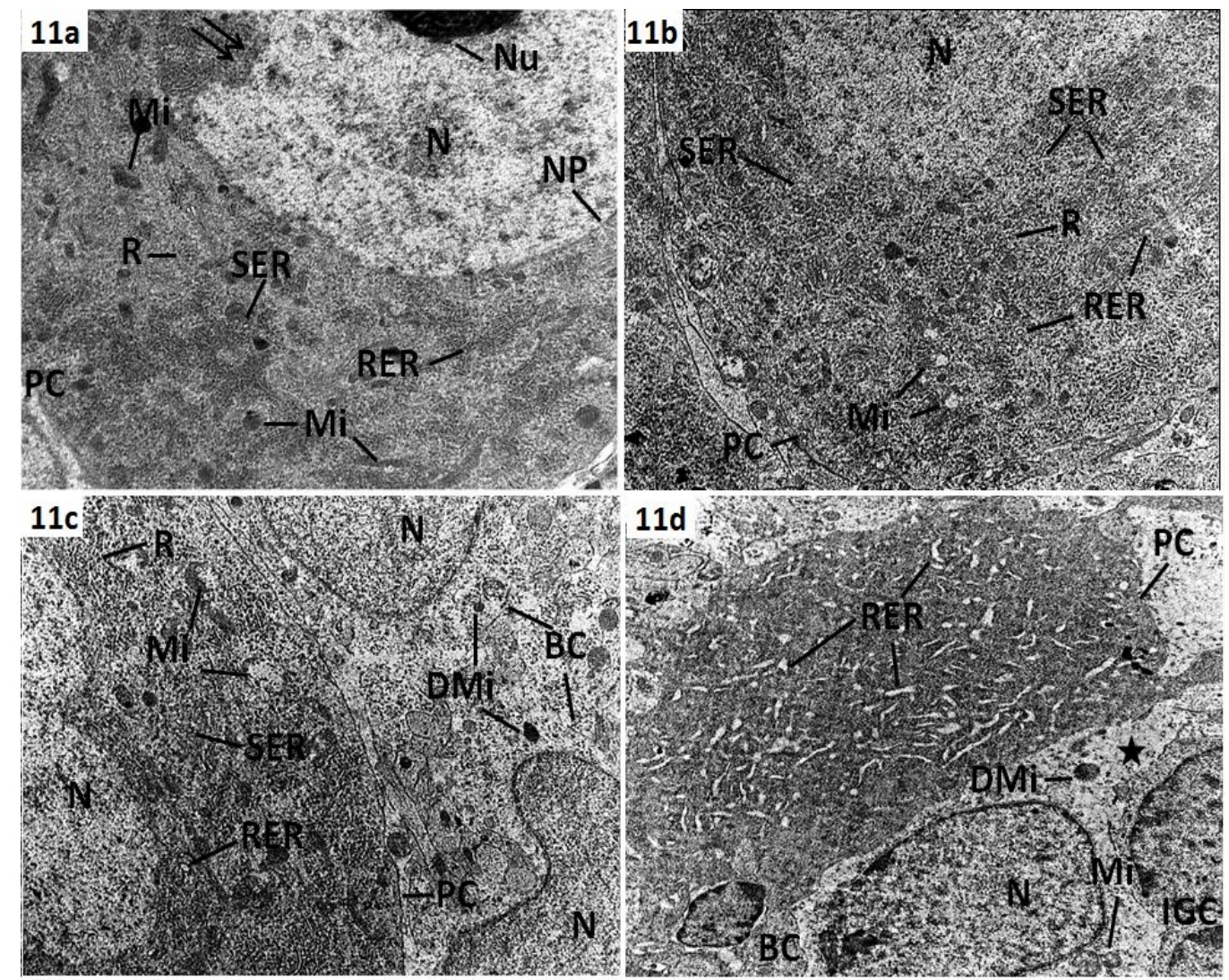

Fig. (11a): An electron micrograph of a part of the Purkinje cell of $\mathrm{C} 1 \mathrm{O} 2, \mathrm{C} 2 \mathrm{O} 2$ and $\mathrm{C} 3 \mathrm{O} 2$ showed that the Purkinje cell (PC) had invaginated ( 2 arrows) euchromatic nucleus (N) with nucleolus $(\mathrm{Nu})$ and apparent nuclear pores ( NP). Its cytoplasm contained free ribosomes (R), rounded or elongated mitochondria (Mi) and smooth (SER) and rough endoplasmic reticula (RER) (TEM X 10000).

Fig. (11b): An electron micrograph of a part of Purkinje cell of T1O2 showed that the Purkinje cell had euchromatic nucleus $(\mathrm{N})$. Its cytoplasm contained ribosomes $(\mathrm{R})$, smooth endoplasmic reticulum (SER) with normal appearance, mitochondria with destructed cristae (Mi) and few dilated rough endoplasmic reticulum (RER) (TEM X 10000).

Fig. (11c): An electron micrograph of a part of Purkinje cell of T2O2 showed that the Purkinje cell had euchromatic nucleus (N). Its cytoplasm contained free ribosomes (R), Smooth endoplasmic reticulum (SER), swollen mitochondria with destructed cristae (Mi) and few dilated rough endoplasmic reticulum (RER). Parts of 2 basket cells (BC) were noticed and had euchromatic nuclei $(\mathrm{N})$ and degenerated mitochondria (DMi) (TEM X 10000).

Fig. (11d): An electron micrograph of a Purkinje cell of T3O2 showed that the Purkinje cell (PC) appeared irregular in shape, shrunken and had numerous dilated rough endoplasmic reticula (RER). Basket cell (BC) was present and had euchromatic nucleus (N), mitochondria with destructed cristae (Mi), degenerated mitochondria (DMi) and areas of undifferentiated structures (Star). Internal granular cells (IGC) were also present (TEM X 10000). 


\section{Effect of fluoxetine hydrochloride on the histological ...}
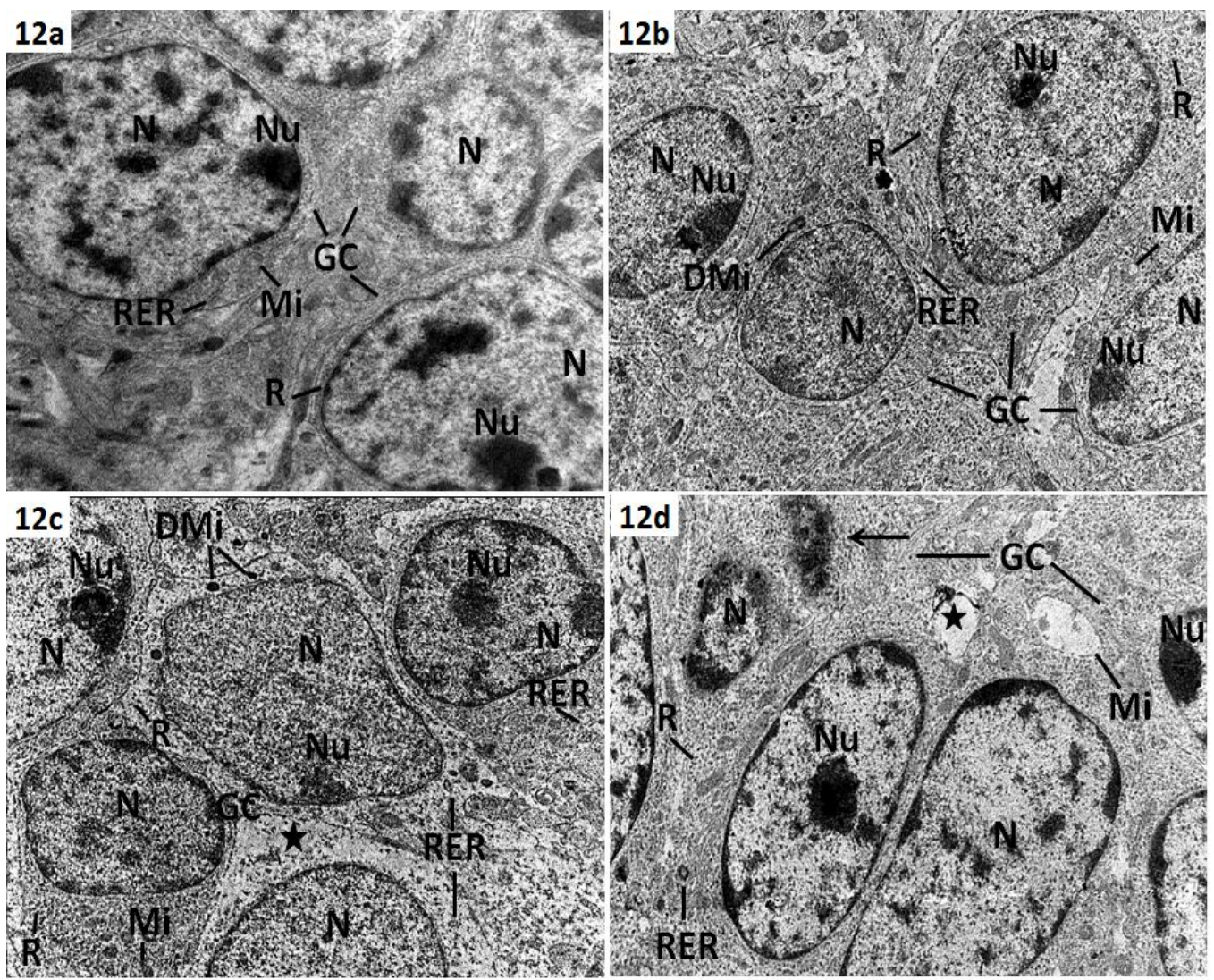

Fig. (12a): An electron micrograph of the granular cells of $\mathrm{C} 1 \mathrm{O} 2, \mathrm{C} 2 \mathrm{O} 2$ and $\mathrm{C} 3 \mathrm{O} 2$ showed that the granular cells (GC) lied close together and had heterochromatic nuclei $(\mathrm{N})$ with eccentric nucleoli $(\mathrm{Nu})$. Their cytoplasm contained free ribosomes $(\mathrm{R})$, rough endoplasmic reticulum (RER), and small rounded or oval mitochondria (Mi) (TEM X 10000).

Fig. (12b): An electron micrograph of the granular cells of T1O2 showed that the granular cells (GC) had heterochromatic nuclei $(\mathrm{N})$ with eccentric nucleoli $(\mathrm{Nu})$. Their cytoplasm contained free ribosomes (R), rough endoplasmic reticulum (RER) with normal appearance, mitochondria with destructed cristae (Mi) and degenerated mitochondria (DMi) (TEM X 10000).

Fig. (12c): An electron micrograph of the granular cells (GC) of $\mathrm{T} 2 \mathrm{O} 2$ showed that some granular cells had euchromatic nuclei $(\mathrm{N})$ with eccentric nucleoli $(\mathrm{Nu})$. Their cytoplasm contained free ribosomes $(\mathrm{R})$, degenerated mitochondria (DMi), dilated rough endoplasmic reticulum (RER) and areas of undifferentiated structures (Star). Other cells had heterochromatic nuclei $(\mathrm{N})$ with eccentric nucleoli $(\mathrm{Nu})$. Their cytoplasm contained free ribosomes, mitochondria (Mi) and rough endoplasmic reticulum (RER) with normal appearance (TEM X 10000).

Fig. (12d): An electron micrograph of the granular cells (GC) of $\mathrm{T} 3 \mathrm{O} 2$ showed that some granular cells had irregular, shrunken nuclei with condensed clumps of heterochromatin $(\rightarrow)$. Other cells had heterochromatic nuclei $(\mathrm{N})$ with eccentric nucleoli $(\mathrm{Nu})$ and their cytoplasm contained free ribosomes (R), swollen mitochondria with destructed cristae (Mi), few dilated rough endoplasmic reticulum (RER) and area of undifferentiated structure (Star) (TEM X 10000). 
Table (1): Thickness of the molecular layer and the Purkinje cell numbers of the cerebellar cortex of the 2-weeks old offspring of C1, C2, T1 and T2

\begin{tabular}{|c|c|c|c|c|c|c|c|}
\hline \multicolumn{2}{|c|}{$\begin{array}{l}2 \text { weeks old } \\
\text { offspring }\end{array}$} & $\begin{array}{l}\text { Thickness } \\
\text { of (ML) }\end{array}$ & Range & P-value & $\begin{array}{c}\text { Number of } \\
\text { (PC) }\end{array}$ & Range & P-value \\
\hline $\mathrm{C} 1 \mathrm{O} 2$ & Mean \pm SD & $\begin{array}{c}161.48 \pm \\
16.25\end{array}$ & $\begin{array}{l}28.69- \\
201.18\end{array}$ & \multirow{4}{*}{0.000} & $51.25 \pm 3.93$ & $45-59$ & \multirow{4}{*}{0.000} \\
\hline $\mathrm{C} 2 \mathrm{O} 2$ & Mean \pm SD & $\begin{array}{c}161.42 \pm \\
15.65\end{array}$ & $\begin{array}{l}29.69- \\
199.8\end{array}$ & & $51.45 \pm 3.35$ & $46-59$ & \\
\hline $\mathrm{T} 1 \mathrm{O} 2$ & Mean \pm SD & $\begin{array}{c}90.57 \pm \\
23.78\end{array}$ & $\begin{array}{l}49.53- \\
128.05\end{array}$ & & $25.80 \pm 3.64$ & $20-32$ & \\
\hline $\mathrm{T} 2 \mathrm{O} 2$ & Mean \pm SD & $\begin{array}{c}64.57 \pm \\
14.72\end{array}$ & $\begin{array}{l}44.29- \\
87.34\end{array}$ & & $15.85 \pm 2.39$ & $12-19$ & \\
\hline \multicolumn{8}{|c|}{ Post Hoc Analysis by LSD } \\
\hline \multicolumn{2}{|c|}{ variable } & $\mathrm{C} 1 \mathrm{O} 2$ vs $\mathrm{C} 2 \mathrm{O} 2$ & $\begin{array}{c}\mathrm{C} 1 \mathrm{O} 2 \\
\mathrm{vs} \\
\mathrm{T} 1 \mathrm{O} 2\end{array}$ & $\begin{array}{c}\mathrm{C} 1 \mathrm{O} 2 \mathrm{vs} \\
\mathrm{T} 2 \mathrm{O} 2\end{array}$ & $\begin{array}{c}\mathrm{C} 2 \mathrm{O} 2 \text { vs } \\
\mathrm{T} 1 \mathrm{O} 2\end{array}$ & $\begin{array}{c}\mathrm{C} 2 \mathrm{O} 2 \text { vs } \\
\mathrm{T} 2 \mathrm{O} 2\end{array}$ & $\mathrm{~T} 1 \mathrm{O} 2$ vs $\mathrm{T} 2 \mathrm{O} 2$ \\
\hline \multicolumn{2}{|c|}{$\begin{array}{c}\text { P value of ML } \\
\text { thickness }\end{array}$} & $>0.05$ & 0.000 & 0.000 & 0.000 & 0.000 & 0.000 \\
\hline \multicolumn{2}{|c|}{$\begin{array}{c}P \text { value of } P C \\
\text { number }\end{array}$} & $>0.05$ & 0.000 & 0.000 & 0.000 & 0.000 & 0.000 \\
\hline
\end{tabular}

ML: molecular layer, PC: Purkinje cell- C1O2: 2- weeks old control albino rat offspring of C1-

C2O2: 2- weeks old control albino rat offspring of C2, T1O2: 2-weeks old albino rat offspring of T1.

T202: 2- weeks old albino rat offspring of $\mathrm{T} 2$.

Table (2): Thickness of the molecular layer and the Purkinje cell numbers of the cerebellar cortex of the 2-weeks old offspring of C2, C3,T2 and T3.

\begin{tabular}{|c|c|c|c|c|c|c|c|}
\hline \multicolumn{2}{|c|}{$\begin{array}{c}2 \text { weeks old } \\
\text { offspring }\end{array}$} & $\begin{array}{c}\text { Thickness } \\
\text { of (ML) }\end{array}$ & Range & P-value & $\begin{array}{c}\text { Number } \\
\text { of }(\mathrm{PC})\end{array}$ & Range & P-value \\
\hline $\mathrm{C} 2 \mathrm{O} 2$ & Mean \pm SD & $\begin{array}{c}161.42 \pm \\
15.65\end{array}$ & $\begin{array}{r}129.69 \\
-199.8\end{array}$ & \multirow{4}{*}{0.000} & $51.45 \pm 3.35$ & $46-59$ & \multirow{4}{*}{0.000} \\
\hline $\mathrm{C} 3 \mathrm{O} 2$ & Mean \pm SD & $\begin{array}{c}161.48 \pm \\
15.83\end{array}$ & $\begin{array}{c}130.68 \\
- \\
200.19\end{array}$ & & $51.55 \pm 3.22$ & $47-58$ & \\
\hline $\mathrm{T} 2 \mathrm{O} 2$ & Mean \pm SD & $\begin{array}{c}64.57 \pm \\
14.72\end{array}$ & $\begin{array}{c}44.29- \\
87.34\end{array}$ & & $15.85 \pm 2.39$ & $12-19$ & \\
\hline $\mathrm{T} 3 \mathrm{O} 2$ & Mean \pm SD & $\begin{array}{c}45.55 \pm \\
6.17\end{array}$ & $\begin{array}{c}32- \\
55.68\end{array}$ & & $11.80 \pm 1.61$ & $9-15$ & \\
\hline \multicolumn{8}{|c|}{ Post Hoc Analysis by LSD } \\
\hline \multicolumn{2}{|c|}{ variable } & $\begin{array}{c}\mathrm{C} 2 \mathrm{O} 2 \text { vs } \\
\mathrm{C} 3 \mathrm{O} 2\end{array}$ & $\begin{array}{c}\mathrm{C} 2 \mathrm{O} 2 \\
\text { vs } \\
\mathrm{T} 2 \mathrm{O} 2\end{array}$ & $\begin{array}{l}\mathrm{C} 2 \mathrm{O} 2 \\
\text { vs } \\
\mathrm{T} 3 \mathrm{O} 2 \\
\end{array}$ & $\begin{array}{c}\mathrm{C} 3 \mathrm{O} 2 \text { vs } \\
\mathrm{T} 2 \mathrm{O} 2\end{array}$ & $\begin{array}{c}\mathrm{C} 3 \mathrm{O} 2 \text { vs } \\
\mathrm{T} 3 \mathrm{O} 2\end{array}$ & $\begin{array}{c}\mathrm{T} 2 \mathrm{O} 2 \text { vs } \\
\mathrm{T} 3 \mathrm{O} 2\end{array}$ \\
\hline \multicolumn{2}{|c|}{$\begin{array}{c}P \text { value of } M L \\
\text { thickness }\end{array}$} & $>0.05$ & 0.000 & 0.000 & 0.000 & 0.000 & 0.000 \\
\hline \multicolumn{2}{|c|}{$\begin{array}{c}\mathbf{P} \text { value of } \mathrm{PC} \\
\text { number }\end{array}$} & $>0.05$ & 0.000 & 0.000 & 0.000 & 0.000 & 0.000 \\
\hline
\end{tabular}

ML: molecular layer, PC: Purkinje cell, C2O2: 2- weeks old control albino rat offspring of C2.

C3O2: 2- weeks old control albino rat offspring of C3, T2O2: 2-weeks old albino rat offspring of T2.

T3O2: 2- weeks old albino rat offspring of T3.

\section{DISCUSSION}

In the present work, it was found that fluoxetine hydrochloride induced various signs of delayed development in the cerebellar cortex of one and two weeks old offspring of treated mothers. These signs were in the form of decrease of the rows of external granular cells in 1-week old offspring, increase the rows of external granular cells in 2-weeks old 


\section{Effect of fluoxetine hydrochloride on the histological ...}

offspring, irregularity in the shape of cerebellar cells, significant decrease of the thickness of the molecular layers. These findings are in line with (Eugenia et al., 2014) who reported that oral administration of therapeutic doses of fluoxetine hydrochloride to the pregnant mice induced various teratogenic pictures in mouse embryos in the form of reduction of foetal body weight, reduction in crown-rump length, still live embryos, delaying of implantation, intrauterine death as well as resorption of embryos, incomplete ossification of most skull bones, irregular and missed ribs, absence of vertebral centra and scoliosis as well as incomplete ossification of both fore and hind limbs. Also, (Silva et al., 2010) reported that postnatal fluoxetine exposure had been found to reduce the number and size of neurons in the raphe nuclei. Also, (Lee, 2009 and Smit-Rigter et al., 2012) stated that in adolescent rat, early postnatal exposure to fluoxetine decreased the dendritic complexity of both thalamocortical afferents and spiny stellate neurons in layer IV of the somatosensory cortex and prenatal exposure reduced the complexity of layer II/III pyramidal neurons in the same region in adolescent and adult mice. Also, (Rayen et al., 2011) said that fluoxetine exposure caused alterations in neurogenesis and the stress response. Postnatal exposure decreased cell proliferation in the hippocampal dentate gyrus in adolescence. Also (Oberlander et al., 2008 ; Kiryanova et al., 2013 ; Olivier et al., 2013; El Marroun et al., 2014 and Rotem-Kohavi and Oberlander, 2017) reported that SSRI exposure during pregnancy was associated with increased rates of preterm births, decreased birth weight, increased risk for congenital malformation, persistent pulmonary hypertension in neonates, neonatal neurodevelopmental and behavioral effects and structural abnormalities of the heart. In addition, (Silva et al., 2008 ; Oliveira et al., 2013 and Vieira et al., 2013) reported that the neonatal manipulation of the serotoninergic system, by fluoxetine and SSRI exposure via placenta and lactation might inhibit the testicular development in prepubertal rats and decreased the number of spermatozoa in adult rats. Moreover, (Foster et al., 2010) stated that environmentally relevant concentrations of fluoxetine might delay the development of tadpoles.

The possible causes of delayed development of the cerebellar cortex may be due to passage of fluoxetine through the placental barrier or milk during breast feeding and the blood brain barrier. After that the fluoxetine may affect the level of serotonin and several genes important for normal development. This suggestion coincides with (Kiryanova et al., 2013) who said fluoxetine and its metabolite norfluoxetine crossed the placental barrier and were excreted in breast milk, resulting in plasma concentrations that could reach therapeutic levels in breast fed infants. Also, (Noorlander, 2008 and Olivier et al., 2011) stated that as in humans, fluoxetine crossed the placental barrier in rats and mice produced a comparable level of fetal exposure. It also crossed the rodent fetal blood-brain barrier, leading to detectable levels of fluoxetine in the blood and brain of pups. Also, (Kaihola et al., 2015 and Olivier et al., 2015) reported that SSRI treatment affected gene expression and protein levels in human placenta and induced changes in nerve growth factor signaling that might influence placental function, and thus, the intrauterine development of the fetus. Also, (Swerts et al., 2010) stated that the prenatal use of fluoxetine in sheep caused acute increase of plasmatic serotonin levels, reduced uterine blood flow and then decreased the availability of oxygen 
and nutrients, induced growth reduction and/or premature delivery. Moreover, (Oberlander et al., 2009 ; Simpson et al., 2011; Kiryanova et al., 2013; Brummelte et al., 2017 and Rotem-Kohavi and Oberlander 2017) reported that acute in utero SSRI exposure lead to higher levels of serotonin in the fetal brain; however, in the long term by means of negative feedback, the development of the serotonin circuitry could be ultimately constrained, lead to reduced serotonergic tone and to lower levels of serotonin in the brain during development. Paradoxically, early shifts in serotonin levels had been linked with an increased risk of the offspring for affective disorders later in life. However, long before serotonin act as a neurotransmitter, it played a critical neurodevelopmental role as a trophic factor shaping the development and function of serotonergic and related systems. serotonin role as a trophic factor started very early in development by regulating various aspects of fundamental developmental processes such as cell growth, differentiation, migration, myelination and synaptogenesis. However, (Warkus, 2018) reported that gene expression analyses showed that various key developmental regulators were affected by fluoxetine, particularly those involved in mesodermal differentiation. Reporter assays demonstrated that fluoxetine inhibited canonical Wnt signaling. Fluoxetine also exhibited cytostatic effects independently of inhibition of the serotonin transporter or canonical Wnt signaling.

In the present work, it was found that fluoxetine induced various signs of degeneration and necrosis in the cells and nerve fibers of the cerebellar cortex of one and two weeks old offspring of fluoxetine treated mothers. These signs were in the form of significant decrease in the numbers of Purkinje cells, cytoplasmic vacuoles, swollen mitochondria with destructed cristae, degenerated mitochondria, dilated rough endoplasmic reticulum and nuclear changes in the form of karyolysis, pyknosis and karyorhexis. These findings are in agreement with (Abdelsalam et al., 2013; Zlatkovic et al., 2014 and Yilmaz et al., 2016) who reported that the sections of liver of rat given fluoxetine exhibited necrosis of hepatocytes, inflammatory cells infiltration, vacuoles, hydropic degeneration, hepatomegaly and steatosis. Also, (Inkielewicz-Stepniak, 2011) reported an increase in serum transaminase levels after a high dose of fluoxetine exposure. Also, (Zidan and Alazouny, 2013) stated that examination of the parotid gland of fluoxetine treated rats revealed marked structural changes in the acini in the form of cytoplasmic vacuoles and irregular displaced nuclei. Other acini were disfigured and coalesced. Cellular infiltration was seen around the excretory ducts and around congested blood vessels. Most acini contained huge dilated cisternae of rough endoplasmic reticulum of several profiles with retained secretion. In addition, (Hajizadeh et al., 2016) reported that fluoxetine treated mice showed drastic morphologic changes in the normal testicular architecture, as evidenced by spermatogenic cell degeneration, disrupted Sertoli cells, intra epithelial vacuolization, and widened interstitial spaces with inflammatory cell infiltration and edematous fluid accumulation. Moreover, (Youssef, 2017) reported that the pancreatic acini of fluoxetine treated adult male albino rats were obviously distorted. The pancreatic lobules were separated by thick interlobular septa, which contained dilated irregular ducts, congested blood vessels and cellular infiltration. The acinar cells had a few vacuoles. Most of the islets of Langerhans were distorted, and shrunken 


\section{Effect of fluoxetine hydrochloride on the histological ...}

and lost. Few islet cells were small in size with small deeply stained nuclei. Most of the acinar cells had irregular shaped nuclei with peripheral heterochromatin. Numerous plasma cells had dilated rough endoplasmic reticulum.

The possible cause of degenerative effect of fluoxetine may be due to increased oxidative stress with decreased antioxidant enzyme activities. This suggestion coincides with (Sakr et al., 2015 and Chen et al., 2015) who stated that experimental studies indicated that fluoxetine decreased antioxidant levels, increased oxidant stress levels by elevating superoxide anion levels, and induced oxidative stress.

In the present work the deleterious effects of the fluoxetine on the cerebellar cortex was directly proportional with increasing doses and durations of its administration. Where, the thickness of the molecular layer and the number of Purkinje cells of the $\mathrm{T} 2 \mathrm{O} 2$ were significantly reduced than those of $\mathrm{T} 1 \mathrm{O} 2$ (Effect of increasing the dose). Also, the thickness of the molecular layer and the number of Purkinje cells of $\mathrm{T} 3 \mathrm{O} 2$ were significantly reduced than those of $\mathrm{T} 2 \mathrm{O} 2$ (Effect of increasing the duration). This finding is in agreement with (Inkielewicz-Stepniak, 2011 and Zidan and Alazouny, 2013) who said that dose-dependent increase of liver injury was reported in rat with fluoxetine. Also, (Eugenia et al., 2014) reported that oral administration of therapeutic doses of Fluoxetine hydrochlorid to the pregnant mice induced various teratogenic pictures in mouse embryos. The embryotoxicity effect was dose dependent. In addition, (Aggarwal et al., 2013) stated that fluoxetine induced sister-chromatid exchanges in bone marrow cells and sperm abnormalities. The response was dose-dependent, and the percentage of sperm count and sperm motility decreased with increase the dose. Moreover, (Kim et al., 2012) reported that short-term exposure (6 h) of 2-cell mouse embryos to doses up to 5-10 ?M fluoxetine increased the number of blastocysts. However, longer exposure to 5 ? M fluoxetine (up to $72 \mathrm{~h}$ ) resulted in a reduction of embryos that developed into blastocysts.

\section{CONCLUSION}

Fluoxetine hydrochloride induced various deleterious changes in the cerebellar cortex of albino rat's offspring of treated mothers. These changes were directly proportional with increasing the dose and duration of its administration.

\section{RECOMMENDATIONS}

The depressed pregnant or lactating mothers must take the lowest dose of fluoxetine for short durations to avoid the exaggerated harmful effects of increasing doses and durations.

\section{REFERENCES}

1. Abdelsalam,O.M.E.; Mohammed, N.A.; Sleem, A.A. and Farrag 4, A.R. (2013): The effect of antidepressant drugs on thioacetamideinduced oxidative stress. European Review for Medical and Pharmacological Sciences; 17: 735-744.

2. Aggarwal, A.; Jethani, S.L.; Rohatgi, R.K. and Kalra, J. (2013): Effect of Fluoxetine on Epididymis of Albino Rats: A Histological Study. International Journal of Scientific \& Engineering Research; 8(4): 1457-1462.

3. Ayaz, T.; Bilir, O. and Ersunan, G (2015): Evaluation of drug intoxications due to suicides. Konuralp Tip Dergisi.; 7 ( 1): 53-56.

4. Bancroft, J. D. and Gamble, M. (2008): Theory and practice of histological techniques. $6^{\text {th }}$ ed. Pbl. Churchill Livingston, Edinburg, pp. 340-348. 
5. Barcellona, P. S.; Fanelli, O. and Campana, A. (1977): Teratological study of etoperiodine in the rat and rabbit. Toxicology; 8(1):87-94.

6. Brummelte, S.; Mc Glanaghy, E.; Bonnin, A. and Oberlander, T.F. (2017): Developmental changes in serotonin signaling: implications for early brain function, behavior and adaptation. Neuroscience; 342:212-231.

7. Chen, H.; Zha, J.; Yuan, L. and Wang, Z. (2015): Effects of fluoxetine on behavior, antioxidant enzyme systems, and multixenobiotic resistance in the Asian Clam Corbicula Fluminea. Chemosphere; 119: 856862.

8. Czeizel , A.E.; Puho, E.H.; Acs, N. and Banhidy, F. (2008): Use of specified critical periods of different congenital abnormalities instead of the first trimester concept. Birth Defects Res. A. Clin. Mol. Teratol.; 82(3):139146.

9. Donald, S.; Risley, Ronald, J. and Bopp (1990): Fluoxetine. Pbl. Elsevier; 19: 193-219.

10. El Marroun, H.; White, T.; Verhulst F. C. and Tiemeier, H. (2014): Maternal use of antidepressant or anxiolytic medication during pregnancy and childhood neurodevelopmental outcomes: a systematic review. Eur. Child Adolesc. Sychiatry; 23:973-992.

11. Eugenia,O.B.; Vari, C.E. and Maria, D. (2014): Fluoxetine effect on gestation and fetal development. Acta. Medica. Marisiensis ; 60(4):157-159

12. Filho, W.O.M.; de Torres, S.M. and Amorim, M.J.A.L. (2014): Fluoxetine induces changes in the testicle and testosterone in adult male rats exposed via placenta and lactation. Systems Biology in Reproductive Medicine; 60 (5): 274-281.

13. Foster, H.R.; Burton, A.Y.G.; Basu, Z. N.; and Wernerk, E. E. (2010): Chronic exposure to fluoxetine (Prozac) causes developmental delays in Rana Pipeins larvae. Environmental Toxicology and Chemistry; 29 (12): 845-850.

14. Hajizadeh, Z.; Mehranjani, M.S.; Najafi, G.; Shariatzadeh, S.M.A. and Jalali, A.S (2016): Black grape seed extract modulates fluoxetine-induced oxidative stress and cytotoxicity in the mouse testis. Jundishapur $\mathrm{J}$. Nat. Pharm. Prod.; 11(2):e27512-e27512.

15. Inkielewicz-Stepniak, I. (2011): Impact of fluoxetine on liver damage in rats. Pharmacological Reports; 63 (2): 441-447.

16. Jin, Y.; Lim, C.M.; Kim, S.W.; Park, J.Y.; Seo, J.S.; Han, P.L.; Yoon, S.H. and Lee, J.K. (2009): Fluoxetine attenuates kainic acidinduced neuronal cell death in the mouth hippocampus. Brain Res.; 1281: 108-116.

17. Kaihola, H.; Olivier, J., Poromaa I. S. and ? kerud H. (2015): The effect of antenatal depression and selective serotonin reuptake inhibitor treatment on nerve growth factor signaling in human placenta. PLoS ONE; 10: 0116459 .

18. Kaihola. H.; Yaldir, F.G.; Hreinsson, J.; H?rnaeus, K.; Bergquist, J.; Olivier, J.D.A.; ? kerud, H. and Sundstr?mPoromaa, I. (2016): Effects of fluoxetine on human embryo development. Front cell Neurosc.; 10: 1-10.

19. Kim C. W.; Choe C.; Kim E. J.; Lee J. I.; Yoon S. Y. and Cho Y. W. (2012): Dual effects of fluoxetine on mouse early embryonic development. Toxicol. Appl. Pharmacol.; 265: 61-72.

20. Kiryanova, V.; McAllister B. B. and Dyck, R.H. (2013): Long-term outcomes of developmental exposure to fluoxetine: a review of the animal literature. Dev. Neurosci.; 35:437-449.

21. Lee, L.J (2009): Neonatal fluoxetine exposure affects the neuronal structure in the somatosensory cortex and somatosensoryrelated behaviors in adolescent rats. Neurotox. Res.;15: 212-223.

22.Leigh, B. and Milgrom, J. (2008): Risk factors for antenatal depression, postnatal depression and parenting stress. B.M.C. Psychiatry; 8:24-25.

23. Mould, R.F. (1989): Introductory medical statistics. $2^{\text {nd }}$ ed. Pbl. Adam Hilger, Bristol and Philadelphia, pp.17-26.

24. Noorlander, C.W.; Ververs, F.F.T.; Nikkels, P.G.J.; van Echteld, C.J.A.; Visser, G.H.A. and Smidt, M.P. (2008): Modulation of 
Effect of fluoxetine hydrochloride on the histological ...

serotonin transporter function during fetal development causes dilated heart cardiomyopathy and lifelong behavioral abnormalities. PLoS One; 3: e2782-e2783.

25. Oberlander, T.F.; Gingrich, J.A. and Ansorge, $\quad$ M.S. (2009): $\quad$ Sustained neurobehavioral effects of exposure to SSRI antidepressants during development: molecular to clinical evidence. Clin. Pharmacol. Ther.; 86:672-677.

26. Oberlander, T.F.; Warburton, W. and Misri, S. (2008): Major congenital malformations following prenatal exposure to serotonin reuptake inhibitors and benzodiazepines using population-based health data. Birth Defects Res. B. Dev. Reprod. Toxicol .; 83:68-76.

27. Olivier, J. D.; Akerud, H.; Kaihola, H.; Pawluski, J. L.; Skalkidou, A. and Hogberg, U. (2013): The effects of maternal depression and maternal selective serotonin reuptake inhibitor exposure on offspring. Front. Cell. Neurosci.; 7:73-74.

28. Olivier, J. D. A.; ? kerud, H.; Skalkidou, A.; Kaihola H. and Sundstr?m Poromaa I. (2015): The effects of antenatal depression and antidepressant treatment on placental gene expression. Front. Cell. Neurosci.; 8:465-466.

29. Olivier, J.D.A.; Valles, A.; van Heesch, F.; Afrasiab-Middelman, A.; Roelofs, J.J.P.M.; Jonkers, M.; Peeters, E.J.; Korte-Bouws, G.A.H.; Dederen.; J.P.; Kiliaan, A.J.; Martens, G.; Schubert, D. and Homberg, J. (2011): Fluoxetine administration to pregnant rats increases anxiety-related behavior in the offspring. Psychopharmacology (Berl); 217:419-432.

30.Oliveira, W.M.; S?, I.R.; Torres, S.M.; Mora is, R.N.; Andrade, A.M. and Maia, F.C.L. (2013): Perinatal exposure to fluoxetine via placenta and lactation inhibits the testicular development in male rat offspring. Syst. Biol. Reprod. Med.; 59:244-250.

31. Paget, G. E. and Barnes, J. M. (1964): Evaluation of drug activities. Pharmacometrics. Vol.1.Pbl. New York Academic Press, pp. 161162.
32. Qiu, C.; Williams, M. A.; CalderonMargalit, R.; Cripe, S. M. and Sorensen T. K. (2009): Preeclampsia risk in relation to maternal mood and anxiety disorders diagnosed before or during early pregnancy. Am. J. Hypertens.; 22: 397-402.

33. Rayen, I.; van den Hove, D.L.; Prickaerts, J.; Steinbusch, H.W. and Pawluski, J.L. (2011): Fluoxetine during development reverses the effects of prenatal stress on depressive-like behavior and hippocampal neurogenesis in adolescence. PLoS One; 6:e24003-e24004.

34. Rotem-Kohavi, N. and Oberlander, T.F. (2017): Variations in neurodevelopmental outcomes in children with prenatal SSRI antidepressant exposure. Birth Defects Res.; Jul 17; 109(12):909-923.

35. Sakr, H.F.; Abbas, A.M.; Elsamanoudy, A. Z. and Ghoneim, F.M. (2015): Effect of fluoxetine and resveratrol on testicular functions and oxidative stress in a rat model of chronic mild stress-induced depression. Journal of Physiology and Pharmacology; 66 (4): 515527.

36. Sengupata, P.R. (2016): Medical pharmacology. $2^{\text {nd }}$ ed. Pbl. New Delhi, Bengaluru, Chennai, Kochi, Kolkata, Mumbai, Hyderabad, Nagpur, Patna, Pune, Vijayawada, pp.383-384.

37. Silva, C.M.D.; Gonçalves, L.; Manhaes-deCastro, R. and Nogueira, M.I. (2010): Postnatal fluoxetine treatment affects the development of serotonergic neurons in rats. Neurosci. Lett.; 483:179-183.

38. Silva, J. V. A.; Lins, A. M.; Amorim, J. A. A.; Pinto, C. F.; Deir, T. B. J.; Oliveira, J. R. M.; Peixoto, C. A. and Manhies-De-Castro, R. (2008): Neonatal administration of fluoxetine decreased final Sertoli cell number in Wister rats. Int. J. Morphol.; 26(1):51-62.

39. Simpson, K.L.; Weaver, K.J. and de Villers-Sidani, E. (2011): Perinatal antidepressant exposure alters cortical network function in rodents. Proc. Natl. Acad. Sci .U S A.; 108:18465-18470.

40. Smit-Rigter, L.A.; Noorlander, C.W.; von Oerthel, L.; Chameau, P.; Smidt, M.P. and 
van Hooft, J.A. (2012): Prenatal fluoxetine exposure induces life-long serotonin 5$\mathrm{HT}_{3}$ receptor-dependent cortical abnormalities and anxiety-like behaviour. Neuropharmacology; 62:865-870.

41. Suvarna, S. K.; Layton, C. and Bancroft, J. D (2013): Theory and practice of histological techniques. $7^{\text {th }}$ ed. Pbl. London, Churchill Livingstone, Elsiver, pp.173-187.

42. Swerts, C. A. S.; Costa, A. M. D. D.; Esteves, A.; Borato, C.E.S. and Swerts, M.S.O. (2010): Effects of fluoxetine and imipramine in rat fetuses treated during a critical gestational period: a macro and microscopic study. Revista Brasileira de Psiquiatria; 32(2): 152-158.

43. Underwood, L.; Waldie, K. and D'Souza, S. (2016): A review of longitudinal studies on antenatal and postnatal depression. Arch. Womens Ment. Health; 19:711-720.

44.

Vieira, M.L.; Hamada, R.Y.; Gonzaga, N.I.; Bacchi, A.D.; Barbieri, M. and Moreira, E.G. (2013): Could maternal exposure to the antidepressants fluoxetine and St. John's Wort induce long-term reproductive effects on male rats? Reprod. Toxicol.; 35:102107.

45. Vigod, S.; Brown, S. and Wilson, C. (2016): Depression in pregnancy. B.M.J.; 352:11547.

46. Vizi, E.S.; Kisfali, M. and Lorincz, T. (2013): Role of non-synaptic GluN2Bcontaining NMDA receptors in excitotoxicity: evidence that fluoxetine selectively inhibits these receptors and may have neuroprotective effects. Brain Res. Bull.; 93: 32-38.

47. Warkus, E.L.L. (2018): Fluoxetine inhibits Canonical Wnt signaling to impair embryoid body morphogenesis: potential teratogenic mechanisms of a commonly used antidepressant. Toxicological Sciences; 165(2): 372-388.
48. Wisner, K. L.; Sit, D. K.; Hanusa B. H.; Moses-Kolko E. L.; Bogen D. L. and Hunker D. F. (2009): Major depression and antidepressant treatment: impact on pregnancy and neonatal outcomes. Am. J. Psychiatry; 166: 557-566.

49. Yilmaz, A.; Elbey, B.; Yazgan, U.; D?nder, A.; Arslan, N.; Arslan, S.; Alabalik, U. and slanhan, H. (2016): Protective effects of caffeic acid phenethyl ester on fluoxetineinduced hepatotoxicity: an Experimental Study. Bio. Med. Research International; 1-8.

50. Youssef, S. (2017): Effect of fluoxetine on the pancreas of adult male albino rats and the possible protective role of omega-3: light and electron microscopic study. International Journal of Clinical and Developmental Anatomy; 3(6): 45-56.

51. Zidan, R.A and Alazouny, Z.M (2013): The effect of fluoxetine on the structure of adult rat parotid glands and the possible role of pilocarpine with nizatidine: a histological and immunohistochemical study.The Egyptian Journal of Histology; 36:869-881.

52. Zlatkovic, J.; Todorovic, N. and Tomanovic, N. (2014): Chronic administration of fluoxetine or clozapine induces oxidative stress in rat liver: a histopathological study. European Journal of Pharmaceutical Sciences; 59: 20-30. 


\title{
Effect of fluoxetine hydrochloride on the histological ...
}

\author{
تأثنير هيدروكلوريد الفلوكستين على التركيب النسيجي لقترة المخيخ لنسل النسل \\ الجرذان البيضاء للأمهات المعالجة \\ أمانى مصطفى أبوعوف
}

قسم التشريح والأجنة ـ كلية الطب (بنات) - جامعة الأزهر

خلفية البحث : هيدروكلوريد الفلوكستين هو أحد مضادات الاكتئاب الأكثر استخداما في فئة مثبطات إعادة امتصاص السيرونونين الانتقائية .

الهذف من البحث: تأثير هيدروكلوريد الفلوكستين على التركيب النسيجي لقشرة المخيخ لنسل الجرذان البيضـاء للأمهات المعالجة

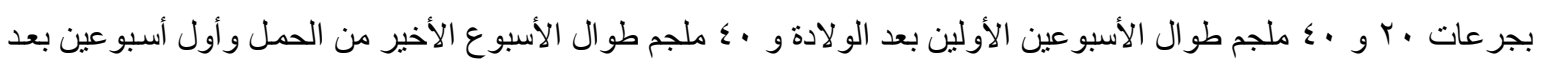
الو لادة.

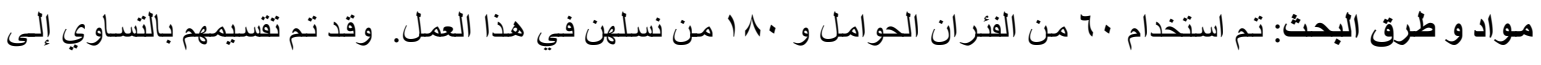

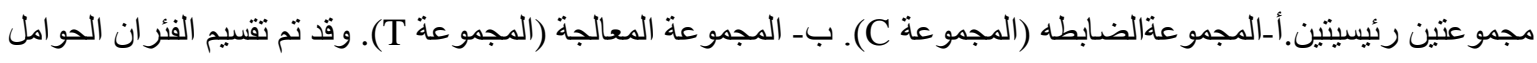

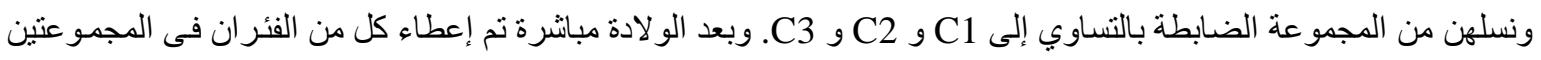

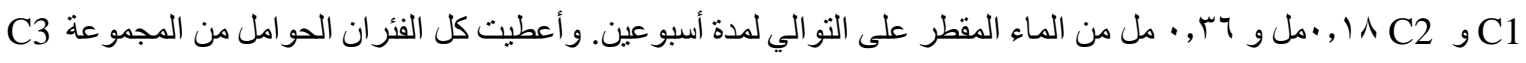

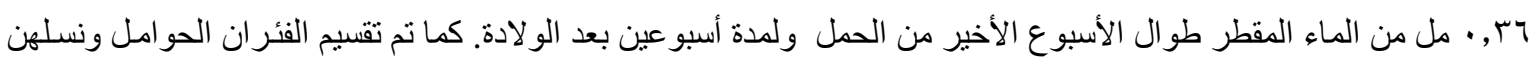

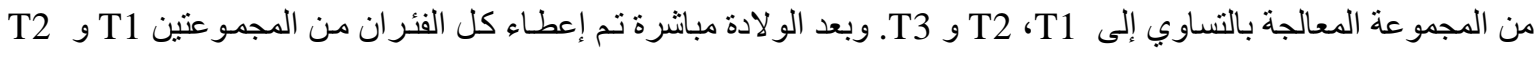

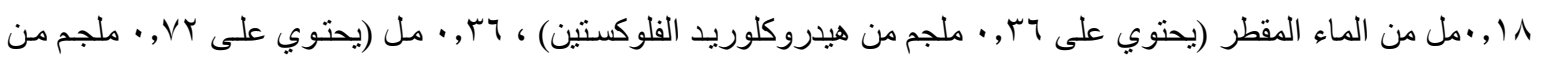

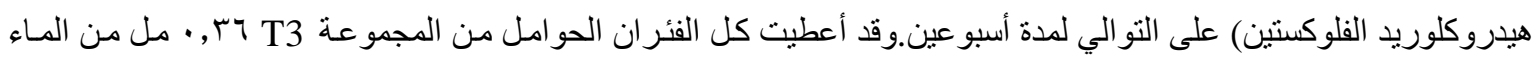

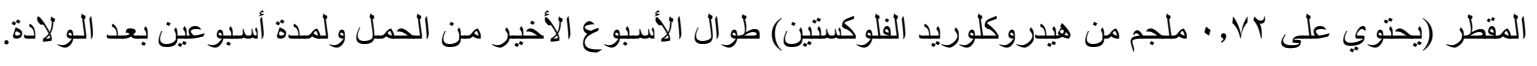

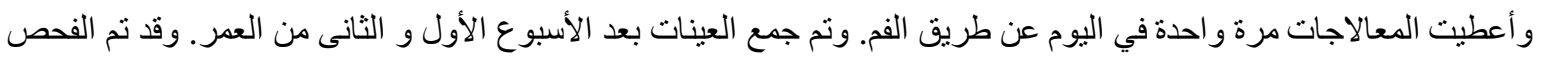

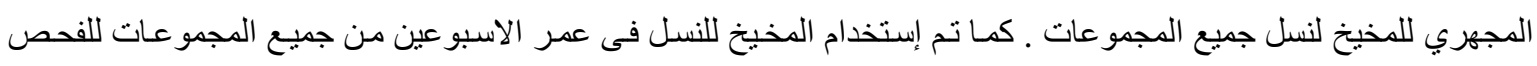
المجهري الإلكترونى والدر اسة المورفومترية.

النتائج: أظهرت الفحصوصات المجهرية الضوئية والإلكترونية و الدراسات المورفومتريـة أن عقار هيدروكلوريد الفلوكستين قد الدان

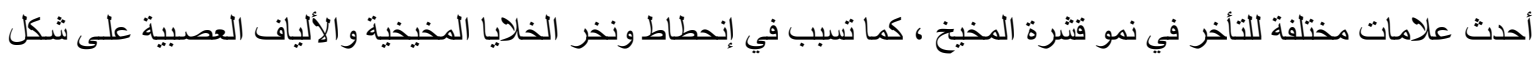

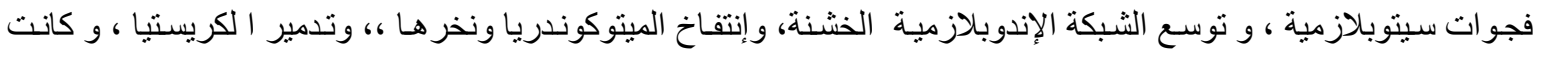

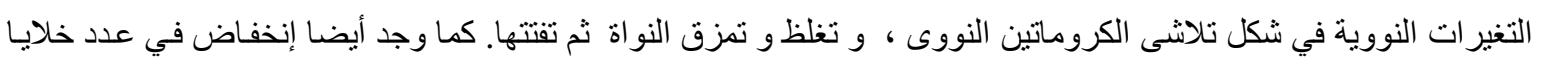
بركنجي.

الاستتتاج: أحدث عقار هيدروكلوريد الفلوكستين تغيير ات مختلفة ضارة في البنية النسيجية لقشرة المخيخ لنسل الجرذان للأمهات المعالجة، وكانت هذه التغيير ات تتناسب تتاسبا طرديا مع زيادة جر عة ومدة إعطاء العقار . 